\section{DIAGNOSIS OF SOURCES OF CURRENT INEFFICIENCY IN INDUSTRIAL MOLTEN SALT ELECTROLYSIS CELLS BY RAMAN SPECTROSCOPY}

By

Donald R. Sadoway

July 29,1988

Work Performed Under Contract No. FG07-82CE40545
For

U. S. Department of Energy Idaho Operations Office Idaho Falls, Idaho

By Materials Processing Center Massachusetts Institute of Technology Cambridge, Massachusetts 


\section{DISCLAIMER}

This report was prepared as an account of work sponsored by an agency of the United States Government. Neither the United States Government nor any agency Thereof, nor any of their employees, makes any warranty, express or implied, or assumes any legal liability or responsibility for the accuracy, completeness, or usefulness of any information, apparatus, product, or process disclosed, or represents that its use would not infringe privately owned rights. Reference herein to any specific commercial product, process, or service by trade name, trademark, manufacturer, or otherwise does not necessarily constitute or imply its endorsement, recommendation, or favoring by the United States Government or any agency thereof. The views and opinions of authors expressed herein do not necessarily state or reflect those of the United States Government or any agency thereof. 


\section{DISCLAIMER}

Portions of this document may be illegible in electronic image products. Images are produced from the best available original document. 


\section{DISCLAIMER}

This report was prepared as an account of work sponsored by an agency of the United States Government. Neither the United States Government nor any agency thereof, nor any of their employees, makes any warranty, express or implied, or assumes any legal liability or responsibility for the accuracy, completeness, or usefulness of any information, apparatus, product, or process disclosed, or represents that its use would not infringe privately owned rights. Reference herein to any specific commercial product, process, or service by trade name, trademark, manufacturer, or otherwise does not necessarily constitute or imply its endorsement, recommendation. or favoring by the United States Government or any agency thereof. The views and opinions of authors expressed herein do not necessarily state or reflect those of the United States Government or any agency thereof.

This report has been reproduced directly from the best available copy.

Available to DOE and DOE contractors from the Office of Scientific and Technical Information, P.O. Box 62, Oak Ridge, TN 37831; prices available from (615)576-8401, FTS 626-8401.

Available to the public from the National Technical Information Service, U. S. Department of Commerce, 5285 Port Royal Rd., Springfield, VA 22161.

Price: Printed Copy A04

Microfiche A01 
DIAGNOSIS OF SOURCES OF CURRENT INEFFICIENCY

IN INDUSTRIAL MOLTEN SALT ELECTROLYSIS CELLS

BY RAMAN SPECTROSCOPY

By

Donald R. Sadoway

July 29,1988

Work Performed Under Contract No. DE-FG07-82CE40545

\author{
Prepared for \\ U. S. Department of Energy \\ Idaho Operations Office, Idaho Falls, ID \\ Sponsored by the Office of the Assistant Secretary \\ for Conservation and Renewable Energy. \\ office of Industrial Programs \\ Washington D. C.
}

\author{
Prepared by \\ Materials Processing Center \\ Massachusetts Institute of Technology \\ Cambridge, Massachusetts
}




\section{TABLE OF CONTENTS}

$\begin{array}{lr}\text { Table of Contents } & 1 \\ \text { Introduction } & 1 \\ \text { Objective } & 3 \\ \text { Results } & 10 \\ \text { Summary. } & 16 \\ \text { Iist of Publications } & 17 \\ \text { Acknowledgements } & \\ \text { Appendices: } & \\ \text { - Cryolite Test Plan } & \text { A } \\ \text {-Excerpt DOE/CE/40545-11 } & \text { B } \\ \text { - Excerpt DOE/CE/40545-15 } & \text { C } \\ \text {-Excerpt DOE/CE/40545-23 } & \text { D } \\ \text {-Excerpt DOE/CE/40545-24 } & \text { E }\end{array}$




\section{Introduction}

It is somewhat ironic that the least dense structural metals, aluminum and magnesium, which can reduce the nation's net energy consumption when used as materials of vehicular construction, are among the most energy intensive metals to produce. The extraction of light metals is achieved for the most part by molten salt electrolysis, a very energy intensive process. In 1986 the production of primary aluminum and magnesium in the United States consumed 2.38 of total generated electricity in this country. This was not 2.38 of the electricity that went to the metals industry, but 2.38 of total generated electricity. The industrial molten salt electrolysis cells that produce these metals operate at power efficiencies of less than 40\%. Clearly, there is much to be gained in terms of energy conservation from technological improvements in the extraction of these metals.

From the standpoint of productivity and international competitiveness, reducing the energy consumption of these extraction processes is a high priority. For example, in the United States the average value for the specific energy consumption of aluminum is $7.2 \mathrm{kWh} / \mathrm{lb}$. When power costs were in the vicinity of $\$ 0.005 / \mathrm{kWh}$ this amounted to approximately 3.6 cents per pound of aluminum. However, in recent years the cost of electricity has risen to the point where some domestic producers are now paying in excess of $\$ 0.035 / \mathrm{kWh}$. At the same time some foreign producers enjoy access to electricity priced below $\$ 0.010$. Thus, the discovery of means to improve the energy efficiency of the smelting process is a way to offset the advantage that derives from low cost power.

This calculation requires a knowledge of metal tonnage [1], generated electricity [1], and specific energy consumption of aluminum [2] and magnesium [3]. 
The potential for energy savings is substantial. On the basis of 1986 figures (see footnote on page 1 of this report) an improvement of 18 in current efficiency represents an annual energy savings of approximately $5 \times 10^{12}$ BTU or 5 milliquads.

Reducing energy consumption in industrial molten salt electrolysis operations has been the goal of many research efforts, which for the most part employed ex situ methods.. Owing to advances in instrumentation there has been a growth in the number of techniques for in situ characterization of electrochemical processes. However, in epite of their potential to reveal the nature of electrochemical phenomena, few of these techniques have been used in the study of molten salt electrolysis because, unfortunately. they are not easy to employ in such extreme environments. A case in point is Raman spectroscopy.

Raman spectroscopy is a technique acknowledged to be extremely valuable in the study of ionic species in which complex formation occurs [4]. Industrial molten salt electrolysis is conducted in precisely such chemistries, i.e., electrolytes in which complex ions are present. Indeed, the electrolyte is typically designed so that the ion of the metal being extracted is fully complexed. For example, in the chloride based electrolytes for electrolysis of magnesium and aluminum the ions of these metals are present as tetrachloromagnesate $\left(\mathrm{MgCl}_{4}{ }^{-}\right.$) and tetrachloroaluminate $\left(\mathrm{AlCl},{ }^{-}\right)$, respectively. In the cryolite based electrolyte used in the Hall-Heroult electrolysis of aluminum its ion is present in a number of fluoroaluminate and oxyfluoroaluminate complexes. While molten salts containing these entities had been studied by Raman spectroscopy, the specific melt compositions were far removed from those employed industrially. Furthermore, there were no reports in the literature of Raman measurements of molten salts during electrolysis. This report summarizes Raman spectroscopy of cryolite based molten electrolytes and includes excerpts from otherwise unpublished project 
quarterly reports in the Appendices for completeness. Previous project work is presented in the published report DOE/CE/40545-20.

Objective

Accordingly, the purpose of this project was to employ Raman spectroscopy in the study of industrial molten salt electrolysis cells. The objective was to improve the understanding of the chemistry and electrochemistry of the relevant melt systems and, in turn, of energy loss mechanisms in the industrial processes. On this basis new ways to improve the energy efficiency of these industrial reactors might be identified.

The research plan had several principal elements. First, there was the design and construction of laboratory scale representations of industrial molten salt electrolysis cells that would at the same time serve a spectrocells. Secondly, there was the mastery of the preparation of the molten salt electrolytes, what in industry is called the "front end". Thirdly, there was the adaptation of commercially available Raman instrumentation in order to facilitate the proposed studies. It is the nature of the specimens that so dramatically distinguished this work from conventional Raman studies for which commercial instrumentation is designed: first, the laboratory scale electrolysis cells are large compared to typical spectrocells; and secondly, the cells operate at, what for Raman studies are, extremely high temperatures.

The range of industrial chemistries investigated spanned chlorides and fluorides: magnesium chloride electrolysis (I.G. Farben chemistry), aluminum chloride electrolysis (Alcoa Smelting Process chemistry), and aluminum electrolysis from cryolite (Hall-Heroult chemistry). This also 
proved to be the order of investigation of the various chemistries:

Results

The results can be classified according to the specific industrial chemistries cited above. Magnesium chloride electrolysis was studied first for two reasons. First, laboratory scale electrolysis cells could be constructed of fused quartz: secondly, there were reports in the literature of Raman measurements of molten $\mathrm{MgCl}_{2}$ and solutions of $\mathrm{MgCl}_{2}$ with various alkali chlorides. Aluminum chloride electrolysis was studied next. The results of both the magnesium chloride work and the aluminum chloride work were described previously in the publicly available topical report, DOE/CE/40545-20 which summarizes the activities of the project from its inception in May 1982 through June 1987.

Hall cell chemistry was the third principal focus of this project. The results of the Raman study of Hall cell chemistry are presented with reference to the "Cryolite Test Plan", a document filed with the contracting officer in September 1987 and reproduced in Appendix $A$.

Part 1: The chemistry of cryolite-based melts

at the time the Cryolite Test Plan was filed it had already been recognized that melt contamination by the container was a potential problem. On the basis of laboratory experiments it had been shown that fused quartz was totally unacceptable and there were doubts as to the degree of inertness exhibited by sapphire.

Fused quartz was unable to contain molten cryolite under the specific furnace conditions of this investigation. The heat transfer 
rates to the solid salt were such that by the time the entire sample had become molten the walls of the cell had been severely attacked. The result was that in some cases the melt broke through the cell wall before data could be taken; in other cases when there was enough time to take data the melt composition had changed so much that the data were meaningless. Certainly the use of fused quartz is to be avolded when one wishes to control the oxygen level of a fluoride melt.

The earliest successful results for cryolite were obtained in spectrocells made of single crystal sapphire tubing. The spectra appear in an article published in Light Metals 1986 and in a quarterly project report, DOE/CE/40545-11 (Appendix B). Attempts to reproduce these results and improve signal to noise ratio were frustrated. One of the problems was the apparent shift to higher wave numbers in the position of the dominant peak. In the early studies this peak was found to be near $535 \mathrm{~cm}^{-1}$ : $535 \mathrm{~cm}^{-1}$ reported in DOE/CE/40545-11 and $533 \mathrm{~cm}^{-1}$ reported in DOE/CE/40545-15 (Appendix C). However, in later studies this same peak was observed at values in the vicinity of $560 \mathrm{~cm}^{-1}$. It became evident after many carefully controlled experiments that this variation was caused by the presence of dissolved oxide. Apparently, even though sapphire was much more resistant to attack by the melt than was fused quartz, there was still enough oxide present even at short times, presumably in the boundary layer at the cell wall, to cause the observed shift in wave number.

The response was to design and construct a spectrocell of material totally resistant to attack by cryolite, or at least a material with corrosion products that are not Raman active and do not alter the spectrum of pure cryolite. The Cryolite Test Plan indicated that one approach was to employ an inert crucible of graphite or boron nitride and to suspend the melt from an inert metal wire helix held above the crucible, the entire crucible and wire assembly contained inside an 
outer fused quartz tube to maintain an inert gas atmosphere. This was attempted with a number of configurations using gold wire, platinum wire, and titanium diboride both in sheet form with a hole drilled through and in rod form for pendant drop studies. The physical chemistry of the system simply was not favorable. The relative surface energies combined the fluidity of molten cryolite caused this design to fail.

The firct epectra of oxide free cryolite were nbrained using the spectrocell described in the project quarterly report DOE/CE/40545-23 (Appendix D). This was the cell in which melt was forced by piston up into a groove cut part way across the sidewall of a cylindrical crucible. The crucible and plunger were composed of inert material such as boron nitride. Under these conditions the dominant peak was located at $\approx 580 \mathrm{~cm}^{-1}$ as reported in the project quarterly report DOE/CE/40545-24 (Appendix E).

To obtain oxide froo cryolite, contain it, ond take its Raman spectrum was an extremely difficult problem. However, the effort to solve this problem led to two important discoverles:

1. there is a relationship between the position of the dominant peak and the $\mathrm{Al}_{2} \mathrm{O}_{3}$ content of the melt.

2. the ratio of cryolite to $\mathrm{AlF}_{3}$ is expressed in the Raman spectrum.

These relate directly to Tasks 1.3 and 1.2 , respectively, of the Cryolite Test plan. The results have been fully described in the above referenced quarterly report. The significance of this work is that the concept of compositional measurement in cryolitic welts by Raman spectroscopy has been demonstrated.

The measurement of cryolitic melts containing $\mathrm{CaF}_{2}$ (Task 1.4 of 
the Cryolite Iest Plan) was attempted without success. Several experiments were conducted. In all cases the spectra appeared identical to those of pure cryolite. This may suggest that calcium is present as a discrete ion, i.e., not part of a complex, and thus is not detectable by Raman spectroscopy.

Careful measurement of the spectra of cryolite in boron nitride and graphite showed no difference (Task 1.5 of the Cryolite Test Plan).

Attempts to measure the spectra of melts to which elemental metal had been added failed. Tasks 1.6 and 1.7 of the Cryolite Test Plan were to look at the effects of additions of aluminum and sodium, respectively. The problem was materials of construction for the spectrocell. Aluminum attacks boron nitride and reacts with graphite. Attempts to use the sapphire cell were foiled. The addition of metal caused the melt to darken and an opaque film to form on the wall of the cell thereby obstructing the beam.

Part 2: Conventional Hall cell electrolysis

Attempts to measure changes caused by the passage of current were unsuccessful. Once electrolysis began, a variety of insurmountable problems presented themselves. First, the signal to noise ratio became unacceptably poor. This meant that it became impossible to appreciate any changes in the spectrum that might occur as a result of the presence of new chemical species. Furthermore, in some cases the electrolyte darkened and an opaque film formed on the inner wall of the cell. The latter was usually a sign of aluminum solubility. All of this was disappointing, as a rather ingenious design of a miniature Hall cell had been developed after considerable effort. Attempts to render the piston spectrocell into an electrolysis cell were unsuccessful. Perhaps there still is some way to take Raman data during electrolysis in a 
laboratory scale, but this remains to be discovered. At this point an approach involving fiber optics is recommended.

Part 3: Effects of impurities on melt chemistry

Owing to experimental difficulties, execution of Parts 1 and 2 of the Cryolite Test Plan took more time than originally anticipated with the result that part 3 received less attention. The only impurity investigated was silicon, which was added to pure cryolite as $\mathrm{SiO}_{2}$. At levels representative of those encountered in Hall cell bath the Raman spectrum appeared identical to that of pure cryolite. At very high levels typical of those found when cryolite attacks fused quartz, the spectrum of cryolite was observed to deteriorate; while no new peaks were observed, for the peaks in the spectrum of pure cryolite itself there was a general broadening along with a decrease in peak-tobackground ratio.

Part 4: Hall cell electrolysis with conventional bath containing impurities

See remarks above in Pare 2.

Part 5: Effects of unconventional additives on melt chemistry

Attempts were made to measure the effects of the addition of $\mathrm{Li}_{3} \mathrm{AlF} \mathrm{F}_{\mathrm{B}}$ on cell bath. Results were disappointing as no change was observed in the spectrum of pure cryolite. However, it should be noted that these experiments were performed early in the investigation. Perhaps if the experiments were repeated with the more advanced spectrocells the presence of $\mathrm{Li}_{3} \mathrm{AlF}_{6}$ might be detectable. Certainly on the basis of the work performed during the course of this investigation it would be inappropriate to dismiss Raman spectroscopy as a useful 
technique in this regard. More study is necessary before a decision can be made one way or the other.

Part 6: Hall cell electrolysis with conventional bath containing unconventional additives: "unconventional bath"

See remarks above in Part 2.

Other studies

As part of a study of bath chemistries that would support a nonconsumable anode the Raman spectrum of $\mathrm{ZrO}_{2}$ dissolved in cryolite was measured. Figure 1 shows the results. The bath consisted of 15 wt: $\mathrm{ZrO}_{2}$ as weighed against cryolite before melting. The temperature of the measurement was $1020^{\circ} \mathrm{C}$ and the excitation radiation had a wavelength of $488 \mathrm{~nm}$. At first glance the spectrum appears identical to that of pure cryolite. However, the main peak is found at a value of wave number shift lower than that of pure cryolite and higher than that of cryolite saturated with alumina. While these results are preliminary they take on significance when viewed in the context of the conclusions cited above about the relationship between alumina concentration and wave number shift of the major peak. While further study is necessary to explain the observation in Figure 1, this still could be a demonstration of the ability of the Raman technique to measure the oxygen potential of the bath as well as metal oxide solubility in general.

In this regard Figure 2 is presented. It shows much the same data as reported in Appendix E, but this time with the aid of the phase diagram on the same page. Clearly, the solubility limit is identifiable in the concentration dependence of the wave number shift. The Raman data give a value of 13 wt at a temperature of $1030^{\circ} \mathrm{C}$. This compares favorably with the value of 14 wto shown in the phase diagram. In 
principle, the same approach could be taken to determine bath compositions and solubility limits in a wide variety of industrially important molten salts. It should be remembered that with the piston spectrocell these measurements are relatively simple to make.

\section{Summary}

Thls pruject begail as an attempt to invegeigete the applicability of Raman spectroscopy to the scudy of the chemistry and electruchemistiy of industrial molten salt electrolysis with the intention of diagnosing sources of loss of current efficiency. The success of this work should then to a large extent be assessed in the light of this objective. What, then, are the accomplishments? The answer to this question has many parts broadly falling into several categories: scientific, technological, and educational.

First, the scientific accomplishments. This was the first study of its kind that sought to use Raman spectroscopy as an investigative tool in the study of the chemistry and electrochemistry of industrial molten salt electrolysis. As such, there were many accomplishments at the laboratory scale that w11l serve as the bas1s for fuluit studies. Among these were the development of laboratory scale representations of industrial molten salt electrolysis cells that simultaneously served as spectrocells; so-called spectroelectrochemical cells. Given the severe chemistries that one encounters in such systems this was not trivial. In 1982, when this investigation began, this kind of hardware was unknown. Today, spectrocells of the type developed in this investigation as well as the furnaces to go with them are showing up in laboratories all over the world. For chlorides, there is the use of fused quartz tubing of square cross section. For fluorides, there is the use of the sapphire single crystal-tubing and the piston spectrocell. These are all products of this invesigation and represent 
advances for the field.

Secondly, there are laboratory techniques that have been introduced into the field as a result of this investigation. Most notably, there is the use of thionyl chloride, $\mathrm{SOCl}_{2}$, in the in situ purification of magnesium chloride melts and aluminum chloride melts.

Now, the technological accomplishments. During the course of this study it became apparent that Raman spectroscopy has the capability to analyze melt composition. In the system, $\mathrm{AlCl}_{3}-\mathrm{KCl}$ (see topical report $D O E / C E / 40545-20)$, this was shown vividly as the Al content was measured from 25 mole $\mathrm{AlCl}_{3}$ down to 1 mole $\mathrm{AlCl}_{3}$. The salient features of this were that the dependence of intensity on concentration of $\mathrm{AlCl}_{3}$ was linear and the calibration curve went through the origin on a plot of intensity versus mole per cent $\mathrm{AlCl}_{3}$. Analogous measurements could be made to determine the concentration of $\mathrm{MgCl}_{2}$ in alkali and alkaline earth halide solvent melts. As molten chlorides do not attack fused quartz readily, the use of fiber optics in order to measure such spectra with a view to determining the melt composition is not out of the realm of possibility and with little effort could be implemented with technology available today.

In the case of fluoride melts, the electroactive species may be involved fin other bonding besides metal-fluorine complexing. Somc of these bonds involved oxygen. The metal-oxygen bond is Raman active. The ability to detect this bond gives one the ability to analyze for oxygen in such melts, a very important control parameter. Again as in the case of the chlorides cited above, one can imagine a system involving fiber optic probes, but in the special case of fluorides these probes would have to be encased in some kind of refractory insulation. In operation the probe tip would be consumable but have a service life longer than the time required to take a measurement. Knowledge of the 
precise oxygen content of the bath would be very useful in a control strategy. For example, this would enhance alumina feeding and allow cells to operate nearer optimum concentration, thereby improving their power efficiency as well as their productivity or space-time yield.

The important point worth making about Raman spectroscopic analysis of melts is that the use of fiber optic probes renders the technique immune to electromagnet1c Interference, an extremely important attribute for a technique to be used in industrial molten salt electrolysis cells where the high electrical currents, typically 100 to $300 \mathrm{kA}$. give rise to intense magnetic flelds. To take meaningful electrical measurements under such conditions requires the use of elaborate shielding and extensive signal processing. Spectroscopic techniques require none of the former and less of the latter.

Finally, the educational accomplishments. The continued sponsorship of this research at MIT over the past 6 years has done much to enhance the infrastructure of molten salt research in this country. Molten salt electrochemistry, and in particular, materials processing by molten salt electrochemistry, is a field of study that has been largely ignored here in the U.S. This in contrast to the sustained efforts in Western Europe and the Soviet Union as well as the strong emerging effort in Japan.

This research project was in many respects the focal point of what was to become for the principal investigetor a portfolio of projects in the field of molten salt electrochemistry to serve as the basis for a molten salt group at MIT. The unique perspective that this molten salt group brings to the field is its emphasis on fundamentals while addressing issues of industrial interest. Furthermore, what makes the study of molten salt electrochemistry in the context of materials processing unique is that the students are made well aware of the 
interrelationships between processing, structure (microstructure and composition), and properties. In this sense, the students who come in contact with this research effort, elther by direct participation through thesis research or indirectly through courses taught by the principal investigator, are exposed to a different set of 1ssues from those encountered in departments of Chemistry or Chemical Engineering.

Finally, the presence of a research effort of this kind has attracted many industrial scientists back to the university campus, as evidenced by the number of such visits documented in the reports filed during the course of this investigation. At a time when policy makers are expressing concern over technology transfer and its effects on international competitiveness the stimulation of such universityindustry interactions should be recognized and applauded. 


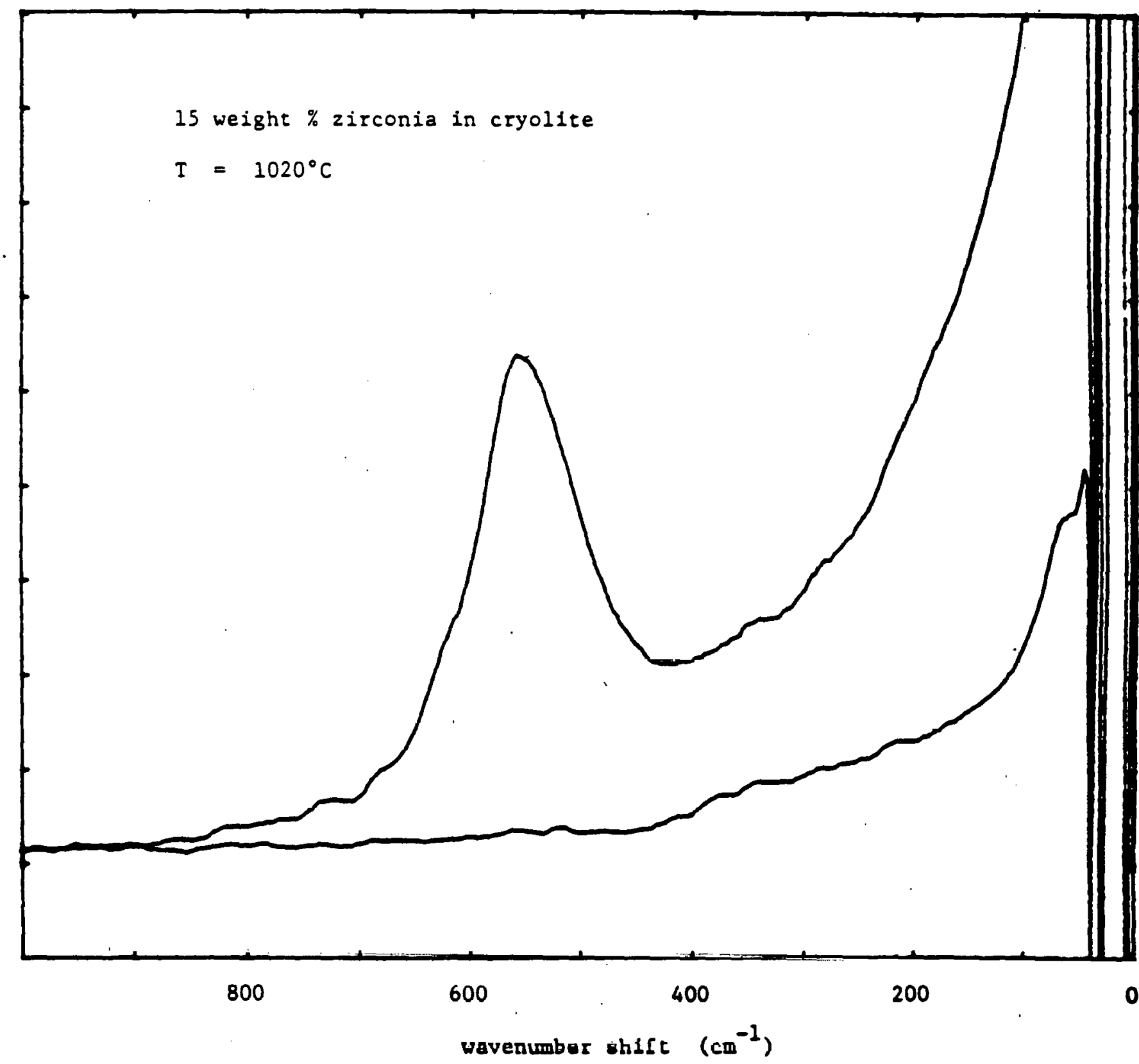

Figure 1. Raman spectrum of 21 irconia in cryolite. 
Figure 2. Raman spectrum of alumina dissolved in cryolite.

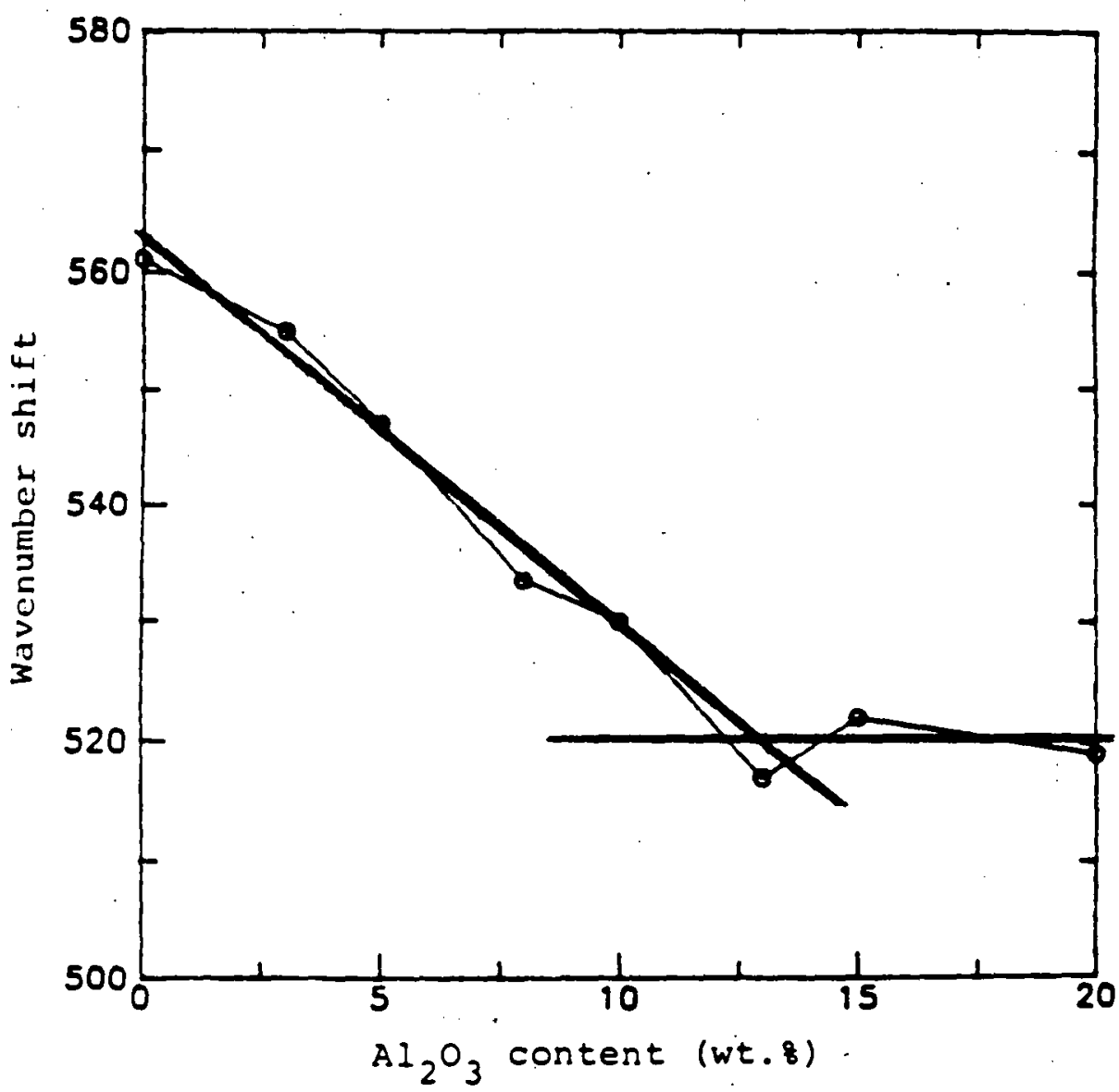

Dependence of wavenumber shift on alumina content in cryolite

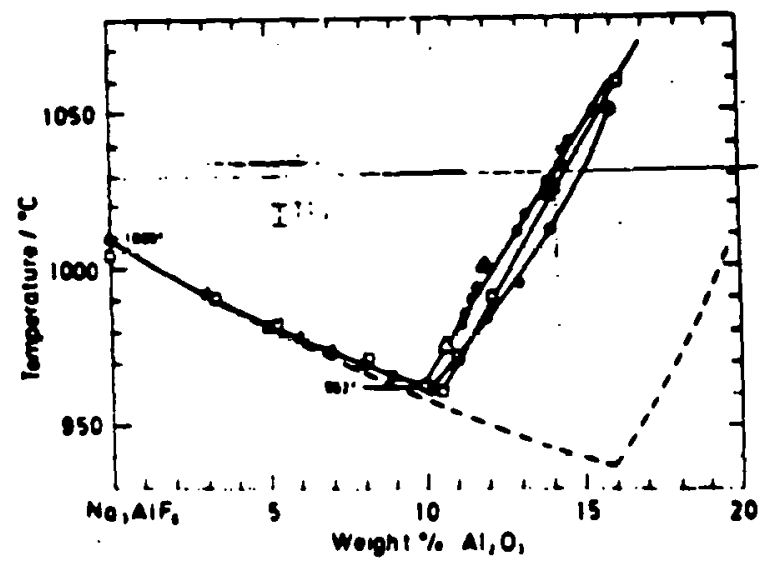




\section{List of Publications}

1. S.PY. Yoon, J.H. Flint, G.J. Klpouros, and D.R. Sadoway, "Raman Scattering Studies of Molten Salt Electrolysis of Light Metals," Energy Reduction Techniques in Metal Electrochemical Processes. R.G. Bautista and R. Wesely, editors, TMS-AIME, Warrendale PA, 1985. PP. 479.490 .

2. G.J. Klpouros, J.H. Flint, and D.R. Sadoway, "Raman Spectroscoplc Investigation of Alkali-Metal Hexachloro Compounds of Refractory Merals," Inors Chem., 24, 3881, 1985.

3. S.YY. Yoon, Y. LiU, J:H. Fline, C.J. Kipouroo, and D.R. Sadoway, "In Situ Raman Spectroscopic Invesigation of Melt Chemistry and Electrode Processes in Laboracory-scale Aluminum Cells," In Lithe Metals 1986, R.E. Miller, editor, TMS-AIME, Warrendale PA, 1986, PP. 479.482 .

4. S.-Y. Yoon, J.H. Fline, G.J. Kipouros, and D.R. Sadoway, "Raman Scattering Studies of Magnesium Electrolysis," In Light Metals 1986, R.E. Miller, editor, MMS-AIME, Warrendale PA, 1986, PP. $1009-1012$.

5. S..Y. Yoon and D.R. Sadoway, "Spectroelectrochemical Study of Magnesium Electrolysis, "in Light Metals 2987, R.D. Zabreznik, oditui, TMS-AIME, Hairondalo FA, 2007, FP. 851-852.

6. G.J. Kipouros and D.R. Sadoway, "The Chemistry and Electrochemisiry of Magnesium Production," in Advances in Moiten Salt Chemistry, Vol. 6, G. Mamantov, C.B. Mamantov and J. Braunste1n, editors, Elsevier, Amsterdam, 1987, pp. 127-209.

7. D.R. Sadoway, "Raman Spectroscoplc Studies of Fused Salt Electrolysis," In Proc 31st Internet. Conp. Pure and Apol. Chem., Sof1a, Bulgaria, Section 7, Phys. Chem., Pp. 172-179.

8. S.-Y. Yoon and D.R. Sadoway, "Spectroscopic and Electrochemical Studies of Molten Salt Electrolysis of Aluminum and Magnesium." in Proceedings of the Joint Intermational Symposiun on Molten Salts. G. Mamintov et al., editors, The Electrochemical Soclety, Punnington NJ, 1987, PP. 1011.1017.

In addition to the above cited publications it is expected that there will be three publlcations based on the doctoral thesis of S.-Y. Yoon. 


\section{Acknowledgements}

Many people contributed to this research. The1r efforts are gratefully acknowledged:

Dr. Seok-Yeol Yoon, who conducted most of the experlwents and took almost all the reported data, designed and constructed all the high temperature spectrocells beyond the first generation including the unique "slotted cell" capable of both containment and "windowless" display of the highly corrosive fluorlde melts, and recognized ways to treat Raman data so as to be able to use the Raman spectroscopy for quantitative analysis of molten salt solutions;

Dr. Georges J. Kipouros, who established the facllitles for purification of salts, bullt the first high temperature spectroelectrochemical cells, conducted the first experiments to obtain Raman spectra of "near Industrial" melts, and during the early stages of this project provided much of the laboratory expertise assoclated with molten salt chemistry in general;

Mr. John H. Flint, who assembled the system for Raman scatrering: studies of molten salts, and helped conduct the first experiments and interpret the data;

Ms. Yachin Liu, who helped with some of the first Raman measurements of cryolite melts.

The research program was funded by the U.S. Department of Energy, Conservation and Renewable Energy, Office of Industrial Programs, and administered through the Idaho National Engineering Laboratory. 


\section{References}

1. B.V. Tllak and J.W. Van Zee, "Report of the Electrolytic Industries for the Year 1986," J. Electrochem. Soc., 234, 297C-316C (1987).

2. T.R. Pritchete et al. "Critical Review of the Office of Industrial Programs' Aluminum Research Program," U.S. Department of Energy Report, DOE/ID:10169, May 1987.

3. T.R. Beck and R.T. Rugger1, "Energy Consumption and Efflclency of Industrlal Electrochemical Processes," in Advences in Electrochemistry and Electrochemical Englneering, Volume 12, H. Gerischer and C.W. Toblas, edicors, Hiley, New York, 1981, PP. 263-354.

4. L.A. Woodward, "General Introduction," in Raran Spectroscopy Theory and Pract1ce, H.A. Szymanski, ed., Plenum, New York, 1967, PP. $231 \cdot 289$. 
APPENDIX A

CRYOLITE TEST PLAN 
The following test plan outlines the experiments to be perforwed under Tasks 6,7, and 8 of Grant No. DE-FG07-82CE40545, Mod. 004. The purpose of the work is to use Raman spectroscopy to determine causes of the loss of current efficlency in Hall cells.

The study plans to look at conventlonal electrolysis, Impurity effects, and unconventional bath additives. At each stage, first the Raman spectra of varlous melts are taken in the absence of electrolysis.

\section{Part 2 The Chemistry of Cryollte-bosed Melts}

Raman spectra will be measured in the absence of electrolysis. For many experiments a monocrystalline sapphire cell will be used. Tests will also be conducted with the melt contained in cruclbles of graphite and boron nitride. In such cases the melt will be suspended from a metal wire helix held above the crucible.

Compositions include the following:

1. Pure cryolite

2. Cryolite + aluminum fluoride at varlous concentrations

3. Cryolite + alumina at various concentrations

4. Cryolite + calcium fluoride

5. Cryolite in the presence of graphite

6. Cryolite in the presence of aluminum metal

7. Cryollte in the presence of sodium netal

8. Cryolite + aluminum fluoride + alumine + calcium fluoride

9. Composition 8 in the preserice of aluminum metal

10. Composition 8 in the presence of sodium metal

The results of Items 2 and 3 will attempt to determine whether Raman spectroscopy can determine bath ratio and alumina concentration, respectively. 


\section{Pert 2 Conventional Hall Cell Electrolysis}

In these experiments, a purified conventional bath is used. Electrolysis will be conducted in anocrystalline sapphire cell with a graphlte anode and graphite cathode block covered with pool of molten aluminum. Bath consists of cryolite, alumina, and aluminum fluoride such that bath ratio is near 1.15. The presence of Caf, will be optional. current density will be varled from $10 \mathrm{~mA} / \mathrm{cm}^{2}$ to $1^{2} \mathrm{~A} / \mathrm{cm}^{2}$.

\section{Part 3 Effects of Impurities on Melt Chemistry}

Raman speclea wlll be measured In the absence of electrolysis. Fux many experiments a monocystelline sepphire cell will be usod. Tosts will also be conducted with the melt contalned in crucibles of graphite and boron nitride. In euch sasec the melt will be cuspended from a metal wire helix held above the crucible.

Compositions include the following:

1. Cryolite + impurity

2. Cryolite + impurity + alumina

3. Cryolite + impurity + graphite

4. Cryolite + impurity + aluminum

5. Cryolite + Impurity + aluminum + graphite

6. Cryolite + impurity + alumina + aluminum + graphite

The impurities to be studied are phosphorus, added as $P_{2} O_{5}$, Iron, added as $\mathrm{Fe}_{2} \mathrm{O}_{3}$, yanadium, added as $\mathrm{V}_{2} \mathrm{O}_{5}$, and silicon, added as $\mathrm{SIO}_{2}$.

\section{Rart 4 Hall Cell Electrolys is with Convenclonal sath Containing Impurities}

Repeat experiments of Part 2 but with Impuritles of Part 3 present in cell bach.

\section{Rart 5 Effects of Unconvenclonal Addifives on Melt Chemistry}

Repeat experiments of Part 3 substituting edditive for impurity. The unconventional additive to be ctudied will be $\mathrm{Li}_{3} \mathrm{AlF}_{6}$. 
Bart 6 Hall Cell Electrolys is with Conventional Bach Containing Uncenventienal Additives: "Unconventional Bath"

Repeat experiments of Part 2 but with additives of Part 5 present in cell bath. 


\section{APPENDIX B}

\section{EXCERPT FROM QUARTERLY PROJECT REPORT}

$D O E / C E / 40545-11$ 
RANAN SCATTERING STUDIES OF MAGNESIUM ELECTROIYSIS

S.-Y. Yoon, J.K. Flint, G. J. Kipouros", and D. R. Saooway

Department of Materials Science and Engineering

Massachusetts Institute of Technolooy

Canbiogot, Hascachusetts 02139

As part of a study of the causes of the loss of current efflelency in industrial agnesjum cejls. the characteristics of laboratory-scale cells are being Investigated by ejectrochemical and spectroscople techniques: Specificaldy. to determine the factors that control the concentrations and opatlal distributions of the various cherical species in the celd, Raman spectra are taken in situ during electrolysis. The electrolyte consists of $11 \%$ MgCl, 65\% NaCl, $18 \% \mathrm{KCl}$, and 6* $\mathrm{CaCl}_{2}$. Cells opefate at a temperaturg of $750^{\circ} \mathrm{C}$ ahd current densitles up to $2 \mathrm{~A} / \mathrm{cm}^{2}$. Spectral informatjon from all identifjable species is correlated with cell operating condjtjons in an attempt to understand the nature of such phenomena as metal fog. streamers, and melt coloration, all of which are observed in these laboratory-scale celis

\section{Introduction}

The extraction of light metals is achieveo for the most part by molten salt eletrolysis, a very energy-intensive process. The production of primary aluminum and magnesium is estimated to have consumed $2.8 \%$ of total generated ejectric power in the United States during the Year $1984(1)$. It is sonewhat jronic that the jeast dense structural metals. Which can reduce net energy consumption when used as wateriajs of vehicular construction, are among the most energy-intensive metals to produce. Thus. research efforts are directed at reducing the energy requirements of these extraction processes.

The electrolytic production of agnesiur -ccounts for about 208 of the total magnesium production in the Western worla(2).

Magnesium production by electrolysis requires 25 - $18 \mathrm{kWh} / \mathrm{kg}$ of magnesium netal. The current efficiency of the anhydrous electrolytic process (I.G. Parben - Norsk Hydrol exceeds 90\%. While that of hydrous electrolytic process (Dow Chemical) is close to $00 \times(3)$.

- Fresent eciòtes: Electrochizilist! Dej.ertnent, General liotors Feseurci: laboratories, har ter. liI 48090 .
As part of a study of the causes of $208 \mathrm{~s}$ of current efficiency, Raman epectra of laboratory-ocale aagnesium chloride ejectrolysis celds are being neasured. Commercially available laser Ranan ecattering instrumentation has been adapted to permit in situ real-time investigation of pedt chemistry and to provide the basis for "fast Raman" spectroelectrocheristry in this and other melt systems. The results of the Raman work are combined with those of other techniques in order to revead the sechanisms and kinetic pathways that decrease current efficiency in vagneslur celds. This paper reports some preliminary Raman data for the electrolysis of anhydrous magnesium chloride.

\section{Literature}

Reasons for the loss of current efficiency are discussed in a recent review of the chetistry and electrocheristry of magnesium production[4]. More inforation is given in the monograph by strelets[5]. Of particular concern to the Raman work is information on melt structure: agnesium does not exist as a discrete cation in chloride Delts but instead in the form of the chlorocomplex. MgC] $[6-8]$. Vibrational spectra confirm this $[9-13]$. However, the purpose of these studies was to deterelne the structure of molten salts, not to understand the electrolytic production of angeslum. As a consequence, melt spectra were not taken during electrolysis. nor were they taken of melts resembling industrial conpositions.

\section{Experibented}

A detalled description of the instrumentation is given in previous reports (14,15). Very briefly. monochromatic lingarly polarlzed laser beam frod ejther an Ar laser (Coherent Innove 901) or $\mathrm{Kr}^{+}$laser (Coherent Innove 90-K) 1rradiates the electrolysis cell which is held inside a specially designed furnace. The scattered light is focused onto the entrance slit of the spectrometer (Spex Industrjes Triplemate 1403 ). An intensified silicon photodiode array (EG\&G PARC Moded 1420-3) serves as detector. The amplifled signal is digjtized in the detector 
controller (RGEG PARC Model 1218 ) and transmitted as data to the optical multichannel analyzer (EG\&G PARC, OMA, Model 22251 .

The polarization state of the exciting radiation is set by a polarization rotaor $(\perp I$ or II). The beam then passes horizontally through the electrolysis cells The scattered radiation is collected at $90^{\circ}$ and is imaged onto the vertical polarization analyzer (It lways). The spectrometgr silt wldth $18100 \mu \mathrm{m}$, equjualent to $\sim 6 \mathrm{~cm}^{-1}$. ryplcally, the spectra were recorded for approximately I anute, corresponding to 200 scans on the OMA. Which was calibrated using the enission lines of a neon lamp in the green. All spectra reported in this article were obtained using the $5 i 4.5$ no line of ergon as exciting radiation.

The electrolysis cell is constructed of optical-grade square fused quartz tubing. I" on inside edge, joined to round tubing 1 mo O.D. The cap 18 a compression fitting made of 304 stainless steel and has ports for the cathode, anode, Inert gas inlet, and thermocouple. The cap also has a sidearm for gas outlet.

The anode 15 wade of high-density graphite rod. 1/8" dia.. usually sllrouded by a fused quartz tube, 3/8"dia. Por the cathode, w1ld steel, 1/4"dia.. TiB, single crystal, I m dia.. or hlgh-density ${ }^{2}$ graphite rod, $1 / 8^{\prime \prime}$ dja.. shrouded by an alumina tube. 3/8" dia.. have all been used.

The preparation of anhydrous salts for electrolyte formulation has been described previously $[14\}$.

In a typical experiment, the electrolysis cell is charged with salt and coserbled with the cap and electrodes in the glove box. The charged cell is placed in the electrical resistance furnace with windows $(14)$, and the salt is melted under high purity argon.

\section{Results and Discussion}

Plgure 1 shows Raman spectra of pure nolten MgCl, at $740^{\circ} \mathrm{C}$. Tpere is a strong polarlzed plak at $205 \mathrm{~cm}^{-1}$ and weak depolarized peak at $385 \mathrm{~cm}^{-1}$. These results ere essentlaliy Identical to those of Huang and Brooker $(10)$. The difference 10 that it took the authors of this report only 4 minutes using the OMA to measure these opectra which Huang and Brooker recorded for eeveral hours. This shows the speed, eccuracy, and sensitivity of the adapted Instrumentation to be satistactory.

Plgure 2 shows Raman spectra of the melt. 78x $\mathrm{NaCl}$ and $22 \times \mathrm{KCl}$. at a temperature of $840^{\circ} \mathrm{C}$. There are no "peaks" like those seen in Plgure d. However, the featurcleas iraces in Figure 2 derive from inelastic scatering and are proper Raman spectra.

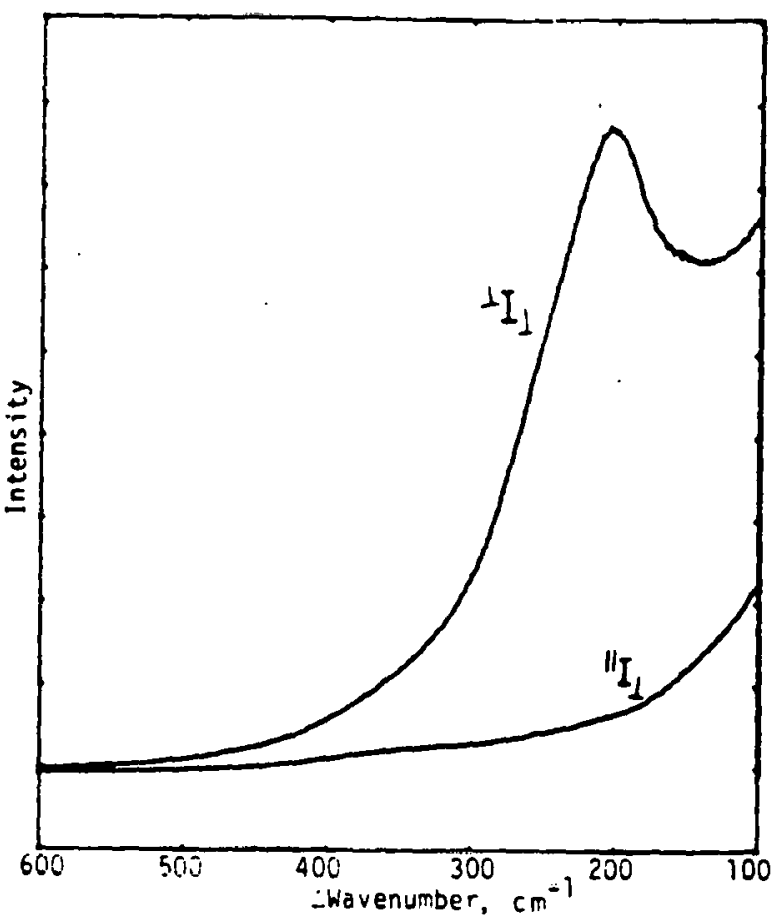

Pig. I Raman spectra of molten magnesium chlorlde at $7+0^{\circ} \mathrm{C}$ :

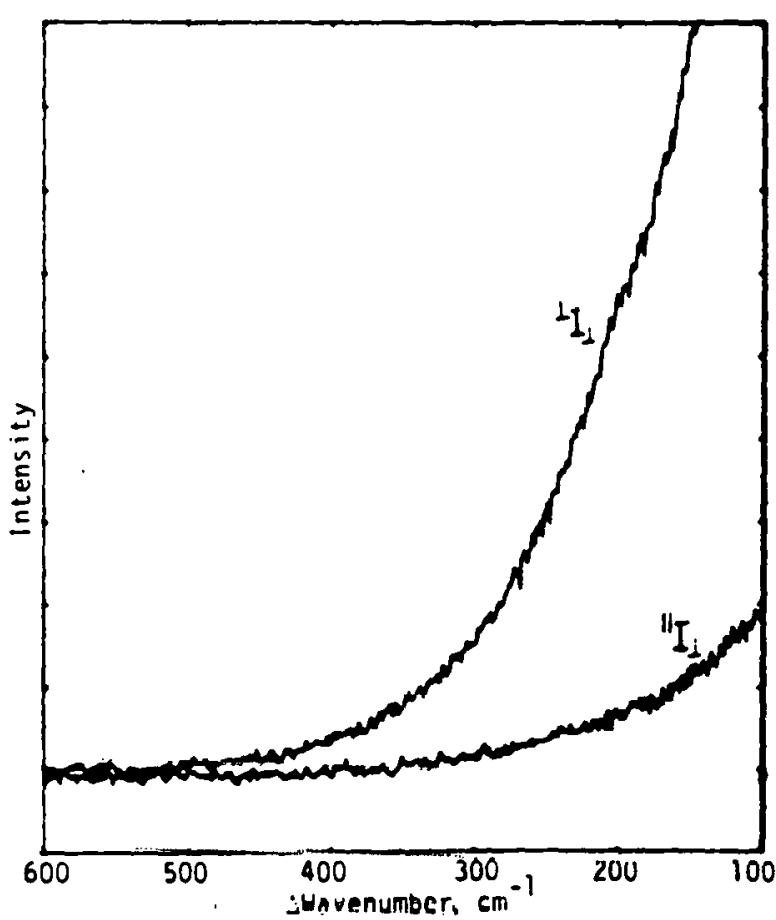

F1g.2 Raman epectra of aodteg $28 \mathrm{w} / 0 \mathrm{NaCl}-22 \mathrm{~W} / 0 \mathrm{KCl}$ at $840^{\circ} \mathrm{C}$. 
Figure 3 shows Raman spectra of the supporting electrolyte. 7\% CaCd, 20* KCl. and $738 \mathrm{NaCl}$, taken a temperature of $850^{\circ} \mathrm{C}$. Somewhat surprisingly, the addition of Cacl to the alkall chloride melt did not give rise to any distinct peaks. It was hoped that one or more such peaks could be used as a standard for calibrating composition during electrolys is experiments. The $\mathrm{CaCl}$ content is not expected to change while magnesium is produced.

Figure 4 shows Raman spectra of medt representative of industrial composition (12x MgCl, 6* CaCl, 65* NaCl, 18* KCll taken t a temperature $8 \pm 750^{\circ} \mathrm{C}$ in the absence of curgent. The prominent polarized peak t, 205 $\mathrm{cm}^{-1}$ in pure $\mathrm{MgCl}$ has shifted to $249 \mathrm{~cm}^{-1}$. During electrolysis there was a decrease in peak helght without, change in wavenumber for the peak at $249 \mathrm{~cm}^{-1}$.

Figure 5 (a) shows a photograph of the cell taken after 1 minute of electrolysis at a current density of $100 \mathrm{~mA} / \mathrm{cm}^{2}$. The composition of the electrolyte was $11 \% \mathrm{MgCl}$, 65* NaCl, 6* CaCl, and $18 \% \mathrm{KCl}$. Temperature was $750^{\circ} \mathrm{C}$. On thê left is a $1 / 4^{\prime \prime}$ graphite cathode: on the right is a $1 / 8$ " graphite anode shrouded with fused quartz tubing. Streamers have begun to emanate from the cathode. Chlorine gas bubbles can be seen on the anode. Figure $5(b)$ shows the same celd as Figure 5(a) after approximately 5 minutes of elgutrolysis at a eurrent density of 100 $m h . c{ }^{2}$. It is evident that the streamers eranating from the cathode have grown over essentially the entire breadth of the cell. The electrolyte has become cloudy. Figure

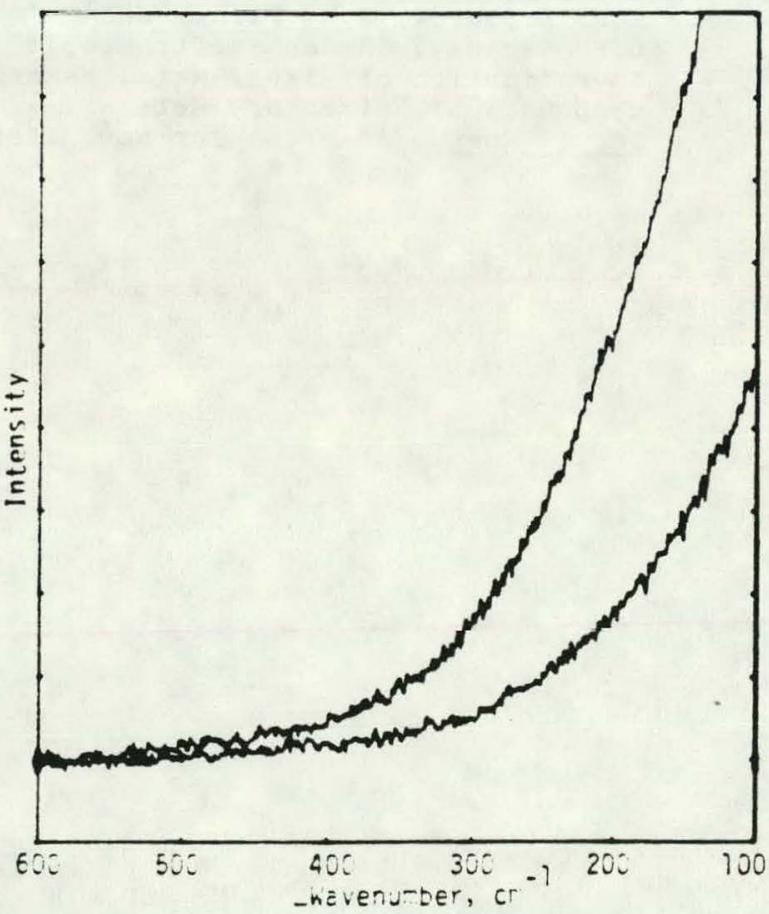

Fig. 3 Raman spectra of molien

$7 \mathrm{~W}$ o CaCi - 20k:O KCl - 73 kio NaCl at $850^{\circ} \mathrm{C}^{2}$

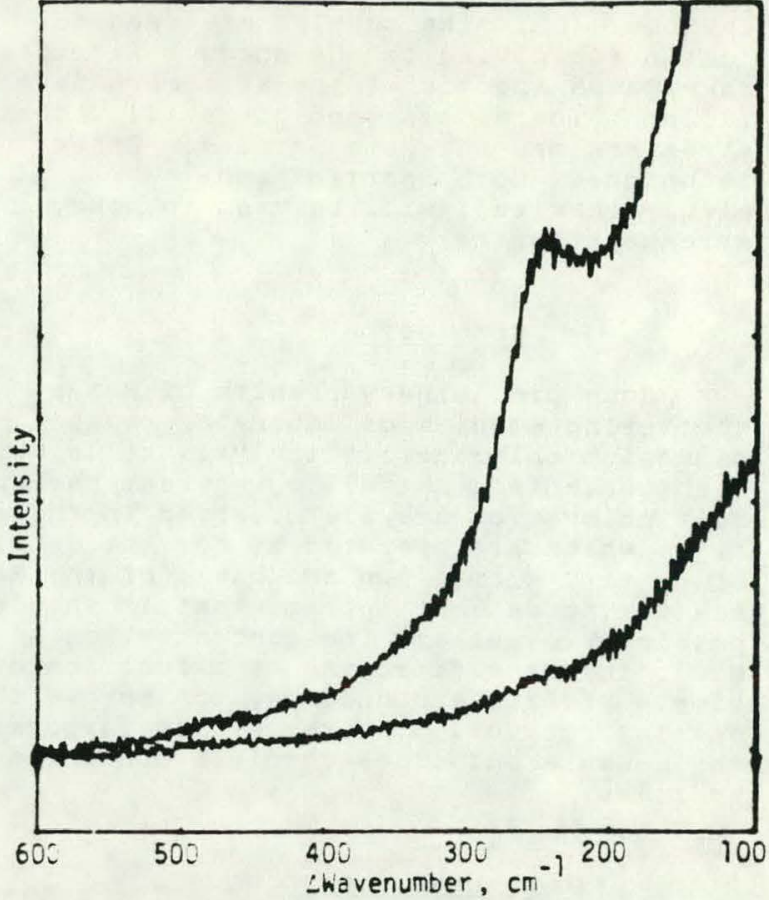

Fig. 4 Raman spectra of molten $1 \mathrm{WW} / 0 \mathrm{MgCl}-6 \mathrm{~W} / 0 \mathrm{CaCl}_{2}-65 \mathrm{w} / \mathrm{O} \mathrm{NaCl}-$
$18 \mathrm{~W} / 0 \mathrm{KCl} \mathrm{at}^{-750} \mathrm{C}$.
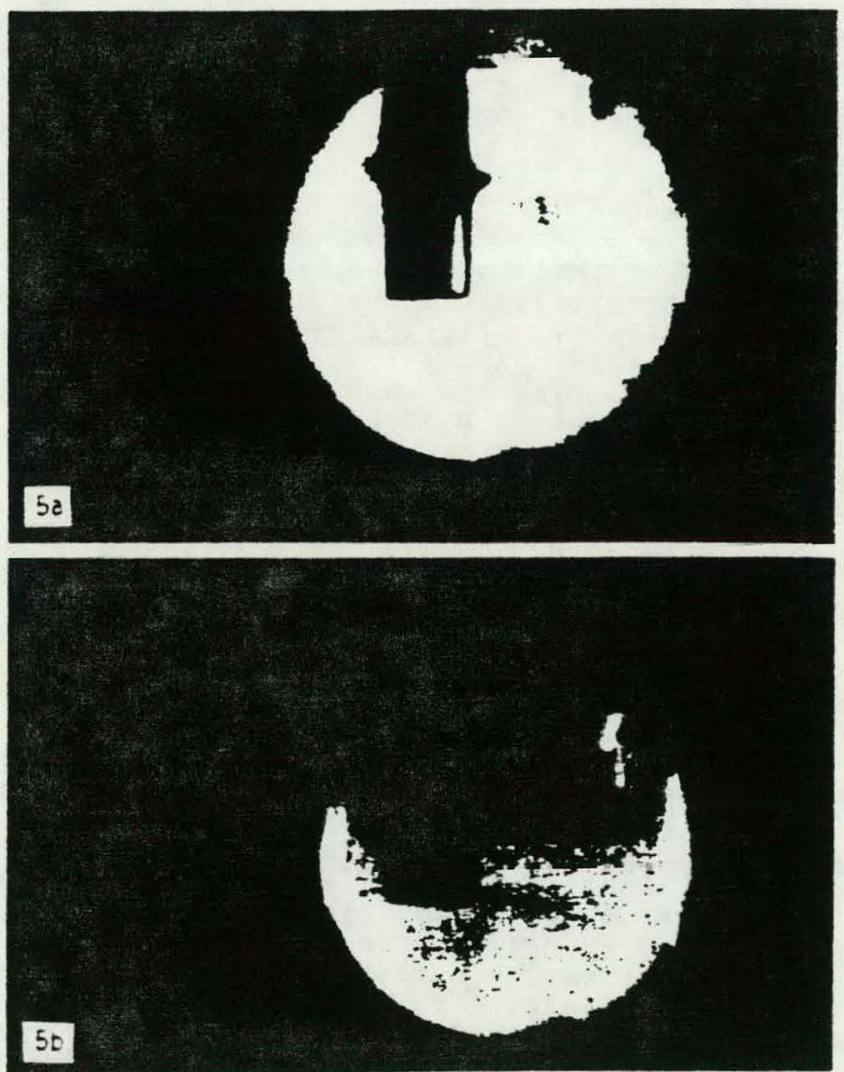

Fig.5 Streamer development in a laboratoryscale magnesium electrolysis cell.

Electrolyte: $11 \mathrm{w} / 0 \mathrm{MgCl}_{2}-6 \mathrm{w} / 0 \mathrm{CaCl}_{2}-$ $65 \mathrm{w} / 0 \mathrm{NaCl}-18 \mathrm{w} / 0 \mathrm{KCl}{ }^{2} \mathrm{~T}=750^{\circ} \mathrm{C}$. ${ }^{2}$ Current density $=100 \mathrm{~mA} / \mathrm{cm}^{2} . \quad$ (a) after 1 minute: (b) after 5 minutes. 
5(b) also shows the appearance of tiny droplets of magnesium on the tip of the cathode. Chlorine bubbles are seen to continue evolving on the anode. Attempts to take Raman spectra of the streamers have failed. There is a good possibility that the streamers are not Raman active. Other techniques, both spectral and electrochemical. will be used to study sireamers further.

\section{Conclusion}

some preliminary results of Raman scattering studies of laboratory-scale magnesium chloride electrolysis cells have been presented. Metal fog. streamers, and melt coloration are all observed in these celis which are, operated at current densities of up to $2 \mathrm{~A} / \mathrm{Cm}^{2}$. On the basis of the Raman scattering data it appears that it should be possible to measure the concentration of possible the electrolyte as a function of $\mathrm{MgCl}_{2}$ in the electrolyte as a to improve the time. Efforts are und the system to perrit spatial resolut of electrolyte concentration profiles.

\section{Acknowledgement}

This material was prepared with the support of the U.S. Department of Energy (DOB) Grant NO. DE-PGO7-82-CE40545. However, any opinions, findings, conelusions, or recommendations expressed herein are those of the authors and do not necessarily reflect the views of DOE.

\section{References} Electrolytic Industries for the Year $1984, " \mathrm{~J}$. Electrochem. Soc., 132 (2) $(1985), \frac{252 C-283 C}{25}$.

2. M.C. Fiemings, G.B. Kenney, D.R. Sadoway, J.P. Clark, J. Szekely, "An Assessment of Magnesium Production Technology, " report to he U.S. Department of Energy. Contract No. EX-76-A-01-02295, Peb. 1, 1981.

3. N. Jarrett, "Advances in the Smedting of Magneslum." in Metallurgical Treatises, J.K. Tien and J.P. Elliott. editors, (warrendale PA : TMS-AIME. 1981). 159-169.

4. G.J. Kipouros and D.R. Sadoway. "The Chemistry and electrochemistry of Magnesiun Production," in Advances in Molten Salt Chemistry, Vol.6, G.Mamantov and J. Braunstein, editors, (Ansterdan : Elsevier, 1986).

5. Kh.L. Strelets, Electrolytic production of Macnesium, trans. by J. Schmorak. (Jerusalem: Keter Publishing House Jerusalem Ltd, 1977).

6. H. Plood and $S$. Urnes. "Dle Berechnung der Aktluatiaten in Magnesium Chlorid Alkallchlorld - Schmelzen aus Structurmodelien." z. Elektrochem. 59

$(1955), 834-839$.
7. D.E. Neil, H.M. Clark, and R. H. Wiswall, Jr., "Thermodynamic Properties of Modten Solutions of $\mathrm{MgCl},-\mathrm{KCl}$.

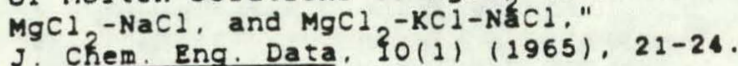
O.J. Kleppa and B.G. MeCarty,

"Thermochemistry of charge-Unsymetrical Binary Pused Halide Systems. II. Mixtures of Magnesium Chloride with the Alkali Chlorides and with Silver Chloride," J. Phys. Chem., 20(4) $(1966)$. 1249-1255.

9. K. Bajasubrahmanyam, "Raman spectra of Liquid $\mathrm{MgCl}_{2}$ and Liquid $\mathrm{MgCl}_{2}-\mathrm{KCl}$ System," J. Chem. Phys.. 44(9) (1966) 3270-3273.

10. C.-H. Huang and M.H. Brooker, "Raman Spectrum of Molten MgCl " Chen. phys. Letters, 43(1) (19i6), 180-182. M.H. Brooker, "A Raman Spectroscopic Study of the Structural Aspects of $\mathrm{K}_{2} \mathrm{MgCl}$ and $\mathrm{Cs}_{2} \mathrm{MgCl}$ as solid single Cfystals and Mólten sajts," J. Chem. Phys..63(7) (1975), 3054-3060.

12. M.H. Brooker and C.H. Huang, "Raman Spectroscopic Studies of Structural Properties of Solid and Molten States of Magnesium Chloride-Alkali Metal Chlnrite Systems." Can. J. Chem., 58 (1980), 168-179.

13. V.A. Maroni. "Vibrational Frequencies and Force constants for retrahedral $\mathrm{MgX}_{4}(\mathrm{X}=\mathrm{Cl}, \mathrm{Br}$, and $I)$ in $\mathrm{MgX}_{2}-\mathrm{KX}$ Melts," J. Chem. Phys., 55(10) (1971), 4789-4792.

14. S. Y. Yoon, J.H. Flint, G.J. Kipouros, and D.R. Sadoway, "Raman Scattering Studies of Molten Salt Electrolysis of light Metals," in Energy Reduction Techniques in Metal Electrochemical Processes. R.G. Bautista and R. Wesely. editors, (Warrendaje PA :TMS-AIME. 1985).

15. G.J. Kipouros, J.H. Flint, and D.R. Sadoway, "Raman Spectroscoplc Investigation of Alkali-Metal Hexachloro compounds of Refractory Metals". Inorg. Chem., in press for Nov. 1985. 
APPENDIX C

¿EXCERPT FROM QUARTERLY PROJECT REPORT

DOE/CE/40545-15 
Following is the Raman spectroscopy technical discussion relevant to cryolite based electrolytes:

\section{Cryolite}

The single crystal sapphire tube, closed at one end, was tested in a spectrocell with molten cryolite. It proved to be able to survive the thermal cycle of heating to $1015^{\circ} \mathrm{C}$, containing molten cryolite, and cooling to room temperature with the solidification of molten cryolites. When the solidified cryolite was dissolved in an aqueous solution of aluminum chloride, the sapphire showed no evidence of etching or loss of transparency.

Cryolite spectra were taken in the sapphire spectrocell. Three stokes (red Raman) shifts were observed: 180, 390, and $533 \mathrm{~cm}^{-1}$. The $533 \mathrm{~cm}^{-1}$ line is strongest and polarized, while the one at $390 \mathrm{~cm}^{-1}$ is weak and depolarized. The $180 \mathrm{~cm}^{-1}$ line is in the anomalous Rayleigh shoulder and is depolarized. The spectrometer was also scanned to deeper red to search for higher wave number Raman shifts. None were detected.

Electrolysis was attempted in a single crystal sapphire tube, open at both ends. The bottom of the tube was plugged with graphite, which also served as the cathode. Unfortunately the seal was poor, and the electrolyte leaked out upon melting. The cell has been redesigned to incorporate a longer cathode plug so that the freeze line forms midway along the plug, i.e., between the bottom of the melt and the bottom of the open-ended sapphire tube. 


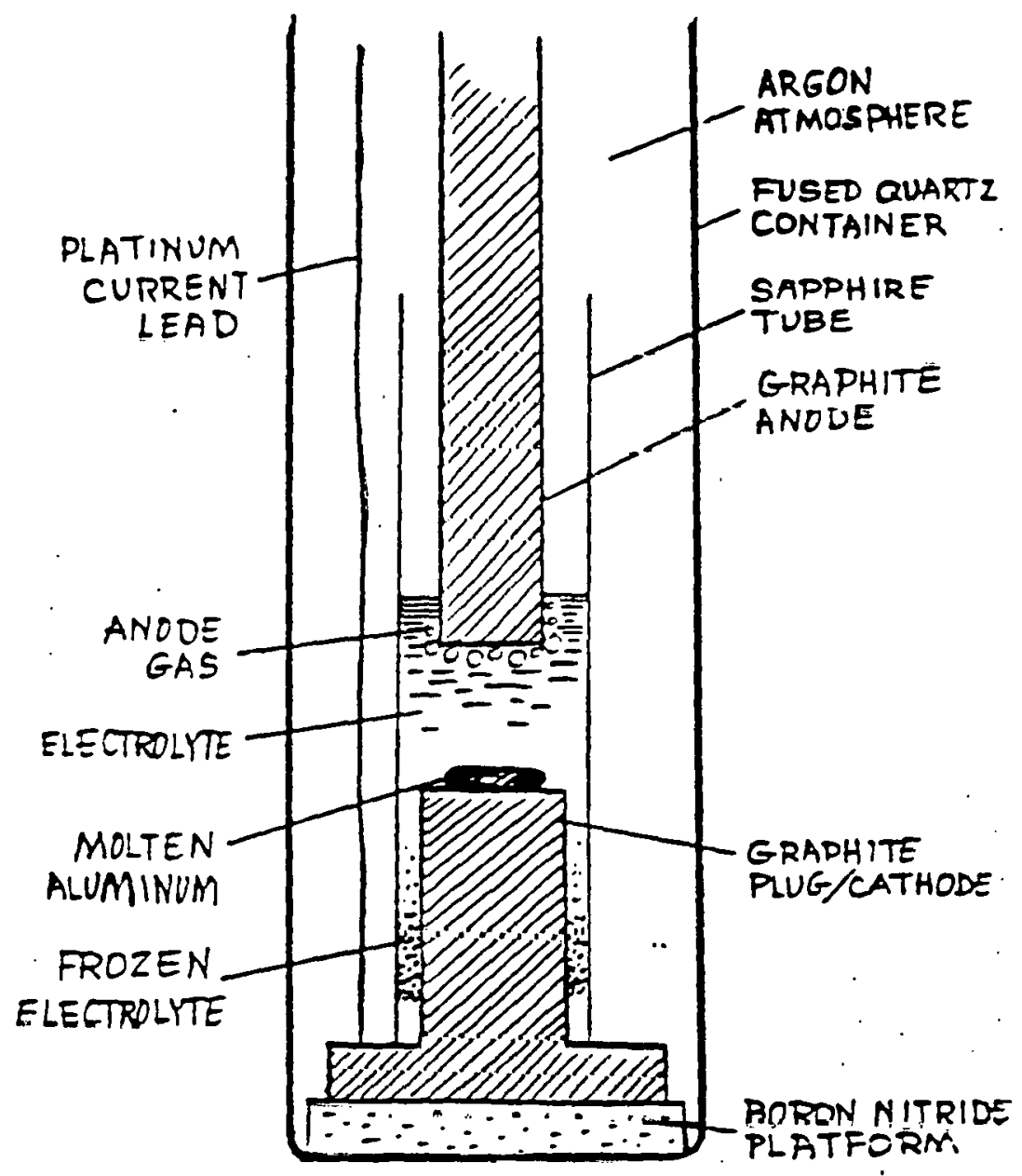

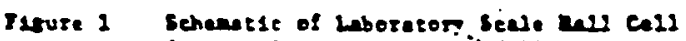

lor oloultaseove knos ind zlectrochenleal

studies. 
APPENDIX D

EXCERPT FROM QUARTERLY PROJECT REPORT

DOE/CE/40545-23 


\section{EXCERPT FROM QUARTERLY PROJECT REPORT \\ $D O E / C E / 40545-23$}

Following is a discussion of research accomplishments from the quarterly project report $D O E / C E / 40545-23$ :

This quarte: was marked by continued attempts to obtain high quality spectro frow the cryolite-based melts. Several designs of spectrucell were constructed and tested with the final result being the invention of athat we believe to be a truly remarkable piece of laboratory apparatus: namely, a spectrocell capable of providing research grade spectra uncer extreme condi. tions. The cell will be described later. But first it is instructive to recount the othe: less successful designs that were tested and to report upon their attributes and shortcorings. All of the comments are in reference to measuring the Raman spectra of cryolite-based melts, i.e., fluoride cheristries.

The first cell consisted of single crystal sapphire tubing. The though: was that although sapphire is attacked by cryolite, the rate of attack would be slow enough to allow the measurement of the spectra of oxidefree fluorice melts. Inis proved not to be the case. Eventually we would learn that the rate of attack and the geometry of the cell would combine so as to Eagrifiy the presence of oxide in the melt even at very short times.

A second cell consisted of a crucible anc hanging rod both of which were contained in an outer closed end fused quartz tube the rop of which was fictec with the siainless steel cap used in the previous chloride studies. Ine crucible and rod were made of inert materials such as boron nitride or graphite. The idea was to hold the melt in the crucible which acted simply as a reservoir. For raking spectra the rod was immersed in the melt to form a penian drop which was held above the crucible in sight of the window of the furnace for illurination by the incioent laser. This arrangement had two problers. First, cryolite would not wet some of the rods. Secondly, the droplet's curved external boundary had a lens effect which threw the laser bear in unwanted dizections uncontroliably and made focussing impossible.

A third cell consisted of a suspended platform onto which droplet of melt sat. Wrile wetzability was not a probiem the lens effect was.

A fourth cell was designed by experimenting with room terperature specire of carbon teirachloride. It was discovered that by flattening the crople = through compression i.e., by essentially squeezing the droplet between two places, the droplet took the shape of e cylinder and the laser bear could be focused. Much experimentation resulted in the discovery of the optimal spacing between the plates to get the best shaped droplet. 
The fifin anc final cell is that shown in Figure l. The wain features are (1) the crucible into which a cross cut has been made half way through so as $=0$ forI $a$ horizorial $E$ ep anc (2) the roc which acts as a ram to force the me $i=$ to rise to the point vinere it is visible in the gap. This exploits the feazures $c$ f the fourtt. cell buz does so in a wuch woze convenient and elegant wanne:. We have tesiec such spectrocells constructeo of graphite and of boron nitride. Tne fincipal atzribute of this cell is that we are able to see the wei: without eijowing it to weke physical consect vith any window raitial such as fused quartz or sepphire: both of which we now know will rafidiy coniarinate the melt with oxygen.

Figure 2 is the spectrur of pure cryolite taken in the spectrocell of Figure 1. The resules are far superior to any achieved to date. Polarizatior: setings are vertical in and vertical out. Of interest is the strong peak: way out at $1463 \mathrm{~cm}^{-1}$. Figure 3 is the same as Figure 2 with the exception that the polarization setrings are horizontal in and vertical out. Note that the strong peak at around $600 \mathrm{~cm}^{-1}$ has completely disappeared which demonsirates full depolarization, sowething that should occur but could not be observec in the spectra obrained previously. There was no explanation for ine peak at $1463 \mathrm{~cm}^{-1}$ at the time. Since then we have learned that this must have beer. a reaction product on the outer fused quartz container. probable due to attack by $A l F_{s}$ bearlng vapor. We hat rever encouncered chis before because our cells had never been robus= enough to pertit us to conduct experiment for such long times, except in the case of the sapphire mono. cr:stal winich simply dissolved as $\mathrm{A}_{2} \mathrm{O}_{3}$ in the melt.

F-Eure 4 shows the spectrum of a solution of 3 weight $\mathrm{Al}_{2} \mathrm{O}_{3}$ in cryo$1 i=e$. There is no evidence of new peaks out around $800 \cdot 900 \mathrm{ca}^{-1}$ as suggesrec by some of the earlier licerature. However, the peak near $600 \mathrm{~cm}^{-1}$ is somerhat atrenuared. Figures 5 and 6 show the spectra of solutions of 5 anc 10 weight $\mathrm{Al}_{2} \mathrm{O}_{3}$ in cryolite, respectively. The artenuarion of the peak near $600 \mathrm{cr}^{-1}$ is stronger as the $\mathrm{Al}_{3} \mathrm{O}$, concentration increases in the pelt. Further investigazion is warranted to determine if a functional relationship car. be estabished between the degree if attenuation and alumina concentra. tion. If so, this would be the basis for a technique for on-line analysis of DE: COMpOSiliun. 


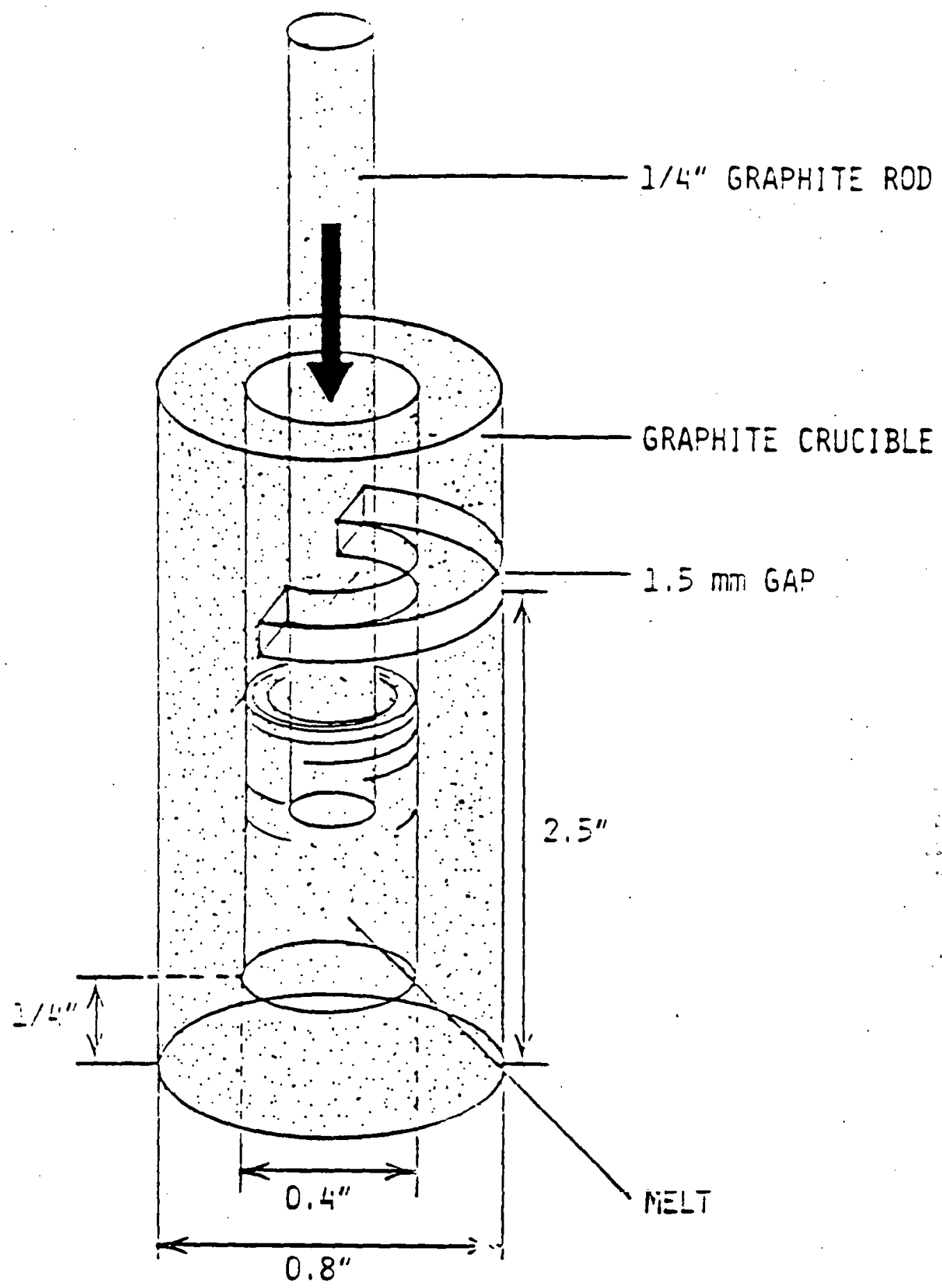

Foure i.

Faman spectroceil for cozosive melis 


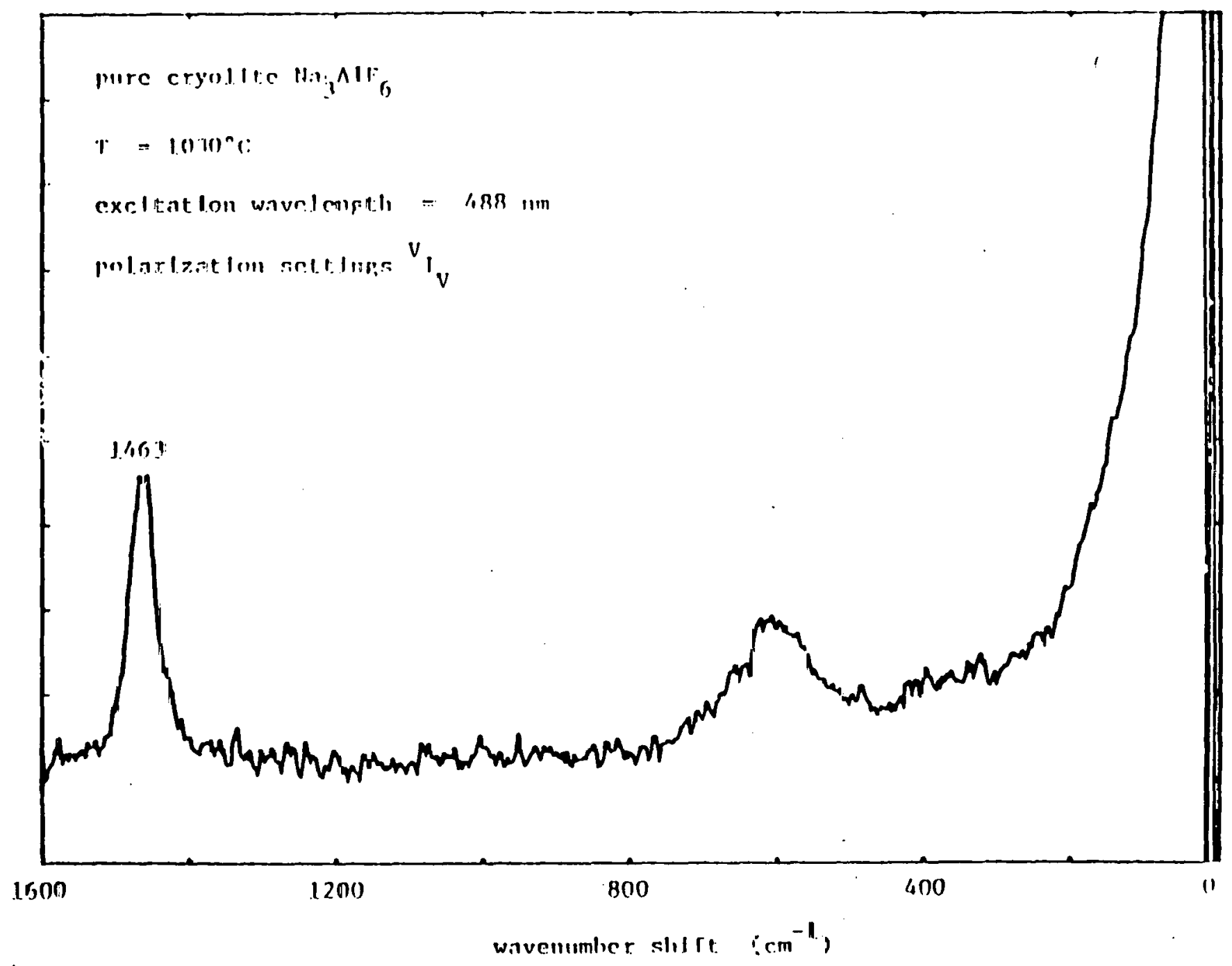

Fipure 2. Raman spactrun of pure cryollte taken lit new spectrocell.

0 


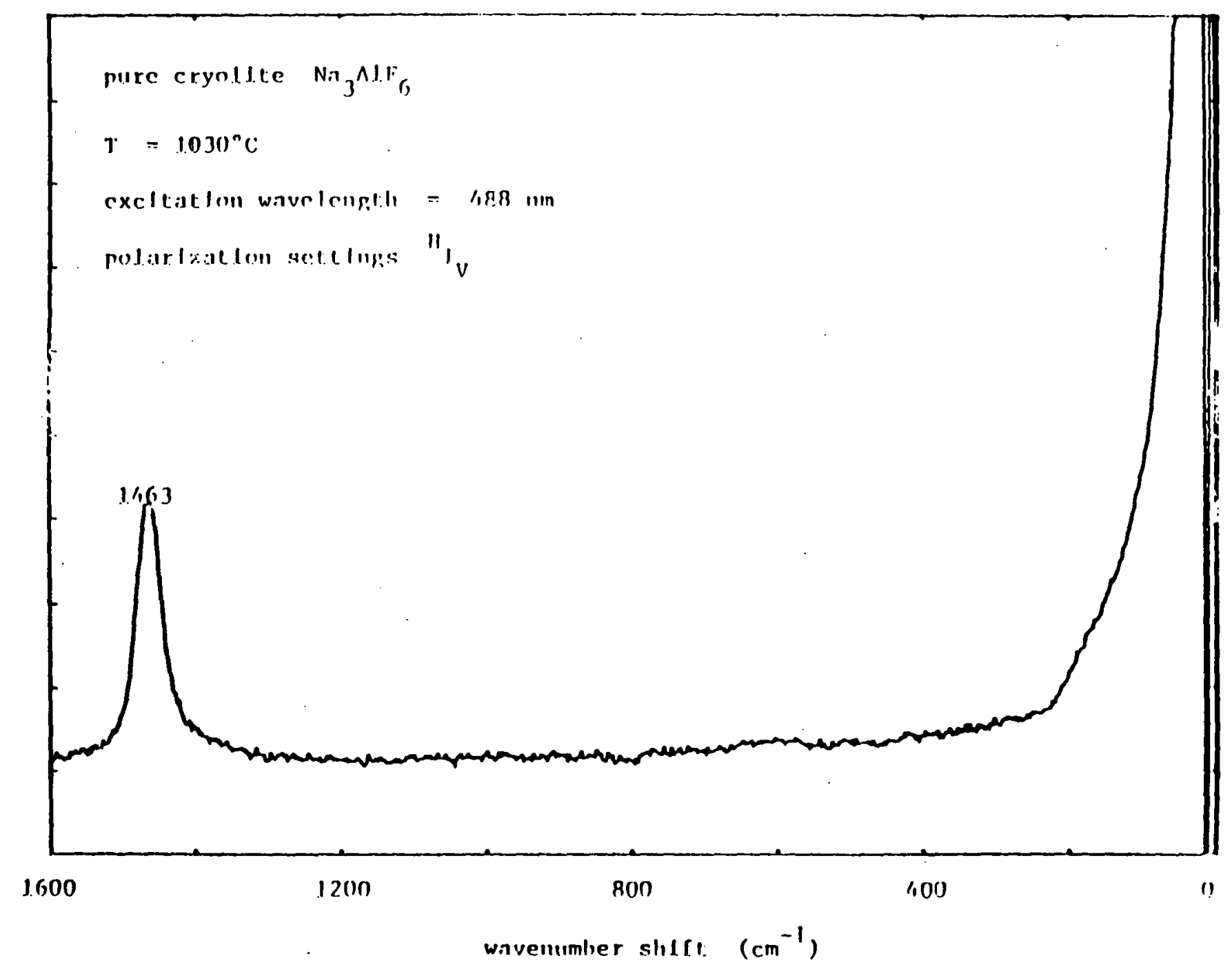

Flgure 3. Kaman spectrum ni pure cryolt te taken in new spectrocell. 


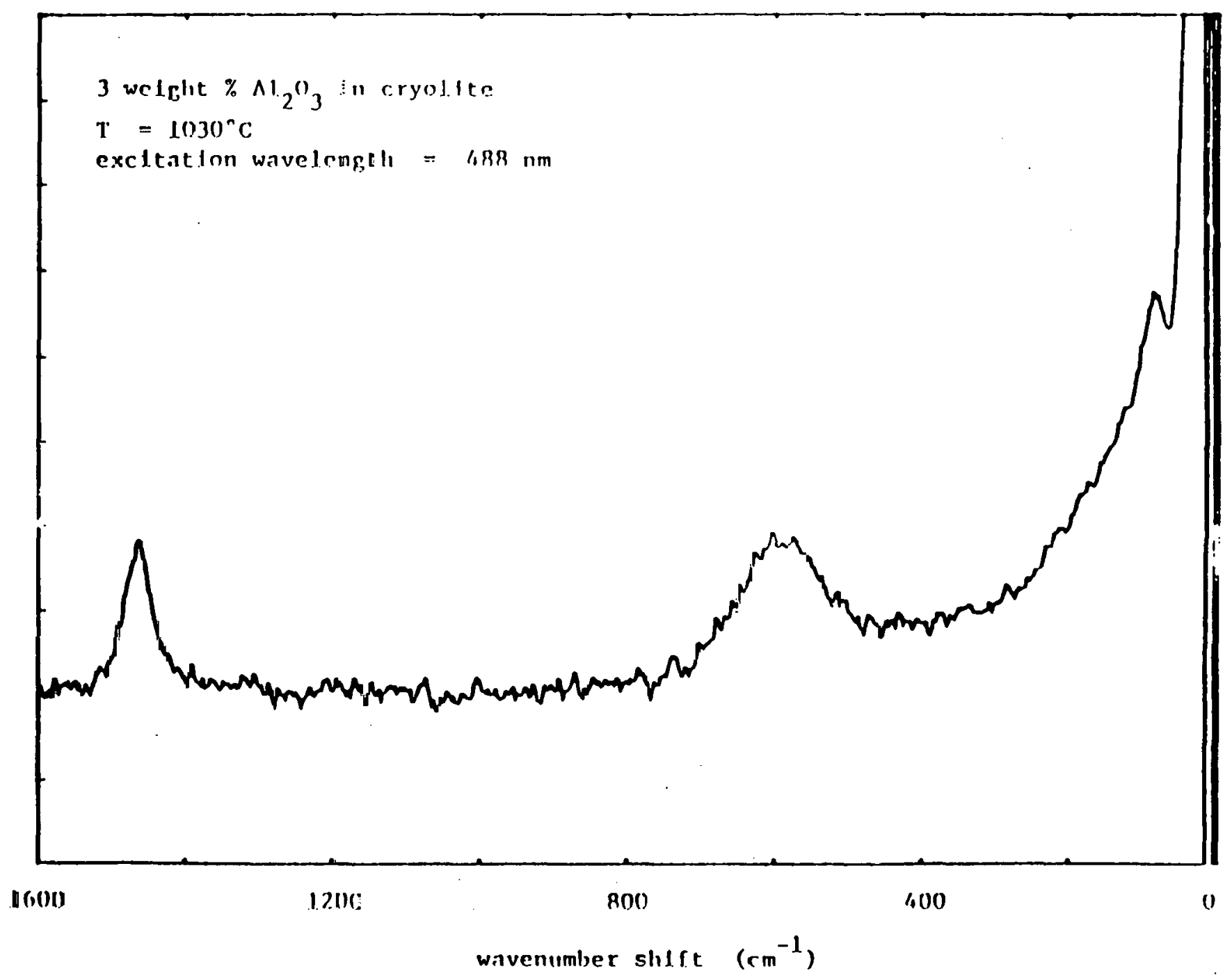

Flgure 1 . Raman spectrum of 3 wt $\% \Lambda_{2} \cap_{3}$ in cryollted 


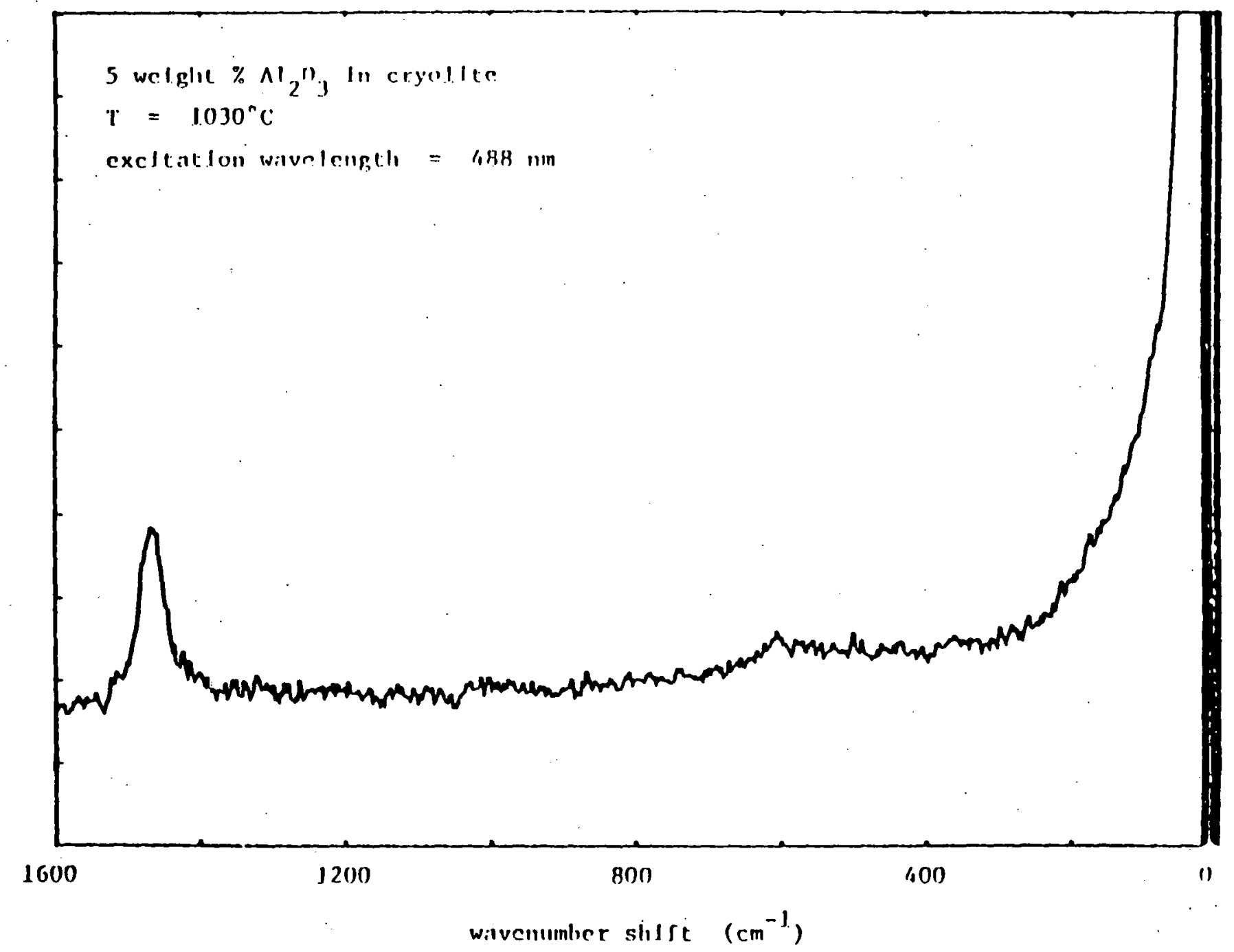

Pigure 5. Naman spectrum of 5 wt $\% \mathrm{N1}_{2}{ }^{\prime}{ }_{3}$ lin cryollee. 


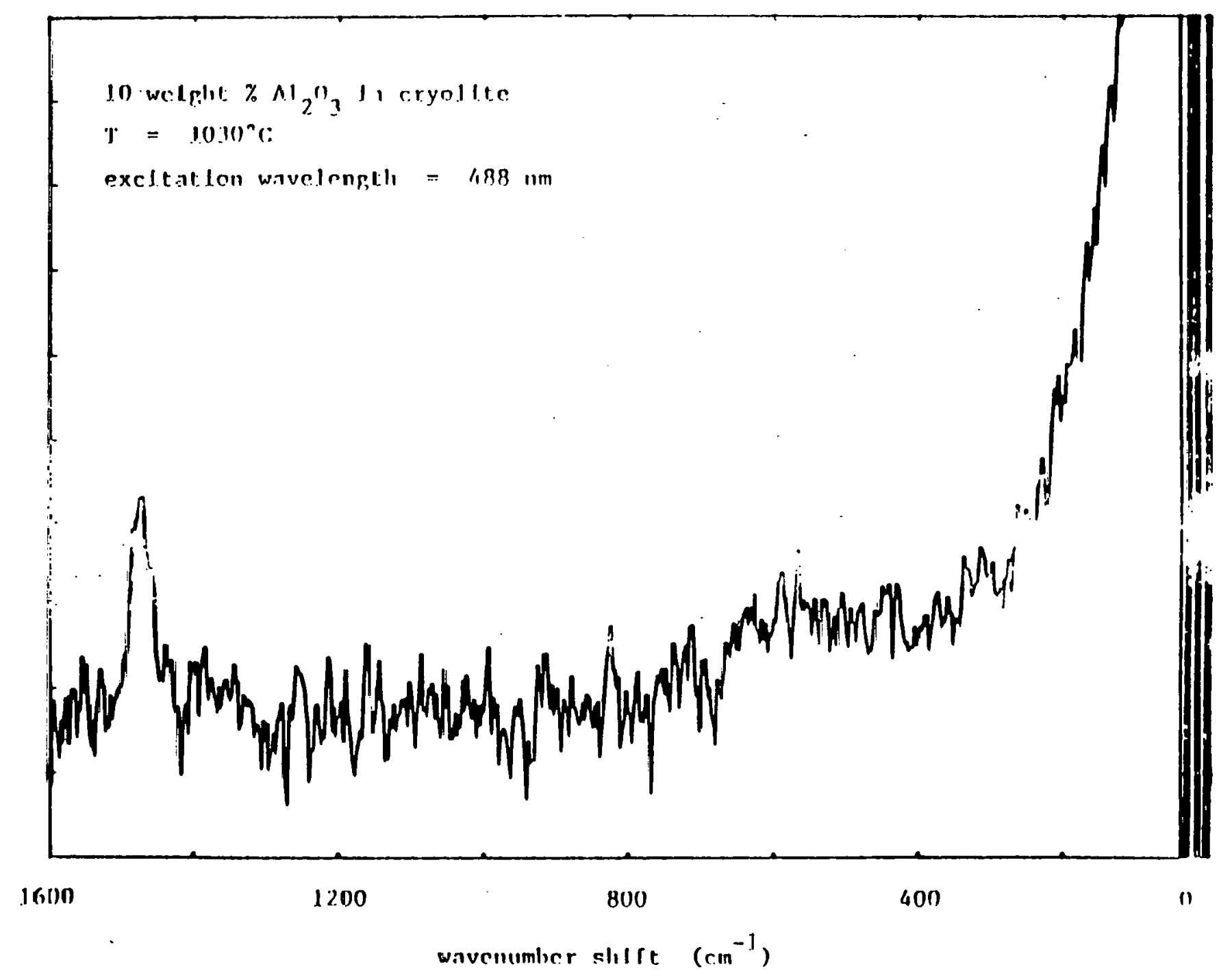

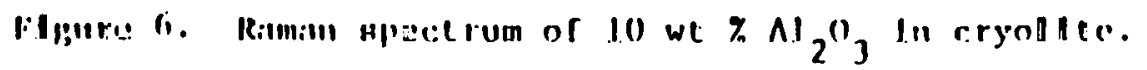


APPENDIX E

EXCERPT FROM QUARTERLY PROJECT REPORT

DOE/CE/40545-24 


\section{EXCERPT FROM QUARTERLY PROJECT REPORT \\ DOE/CE/40545-24}

Following is a discussion of research accomplishments from the quarterly project report DOE/CE/40545-24:

This quarter was marked by the taking of a large amount of data. The spectrocell described in the previous report, DE/CE/40545-23, proved to be a workhorse. The results will be described according to campaigns.

One set of experiments sought to determine whether Raman spectroscopy could reveal the state of chemlcal coordination in the fluoroaluminate com. plexes present in cryolite based electrolytes. A series of melts containing

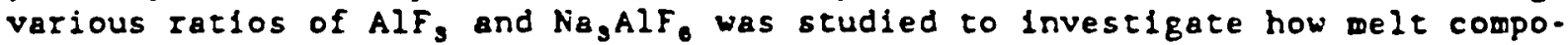
sition or, more specifically, bath ratio affects the complexing and coordination. The dominant reaction under these conditions is

$$
2 F^{\circ}+A 1 F_{4}^{-}-A 1 F^{3-}
$$

which can also be thought of in terms of an acid-base equllibrium in which AlF. - acts as the acid and $F^{\circ}$ acts as the base. Strictly speaking, the bath ratio is the ratio of NaF to AlF, by weight. Related to this is the cryolite ratio which is the ratio of NaF to AlF, on molar basis.

Figure 1 shows the Raman spectrum of a melt conteining $A 1 F_{3}$ and $\mathrm{Na}_{3} \mathrm{AlF}_{6}$ in a 1:1 mole ratio. The temperature of the melt was $870^{\circ} \mathrm{C}$, and the excita. tion radiation had a wavelength of $488 \mathrm{~nm}$. The spectrum is of superb quality. There are several reasons for this. First, the melts were of high purity due to our careful preparation procedures which involved premelting. Secondly, the spectrocell allowed us to avoid contaminating the melts during the course of taking the data. Thirdly, with the equipment modifications described previously, data processing was greatly enhanced in terms of our abilicy to do curve swoothing, plotting, analysis, etc. There are five peaks in Figure 1: $210 \mathrm{~cm}^{-1} \mathrm{dp}, 330 \mathrm{~cm}^{-1} \mathrm{dp}, 625 \mathrm{~cm}^{-1} \mathrm{p}, 760 \mathrm{~cm}^{-1}$ $d p$, and $580 \mathrm{~cm}^{-1} \mathrm{p}$. The first four fit the pattem for a tetrahedrally coordinated complex, which in this case is obviously AlF. . The peak at 580 $\mathrm{cm}^{-1}$ is on the shoulder of the major peak at $625 \mathrm{~cm}^{-1}$ and represents the major peak of pure cryolite. As such it is a representation of octahedral coordination as expected in $A_{1 F_{6}}{ }^{-}$.

Figure 2 shows the Raman spectrum of a melt contalning $A l F_{3}$ and $\mathrm{Na}_{3} A l F_{6}$ in a $3: 4$ mole ratio. The temperature of the Delt was $890^{\circ} \mathrm{C}$, and the excitation radiation had a wavelength of $488 \mathrm{~nm}$. The same five peaks as those present in Figure 1 appear in Figure 2. However, In Figure 2 the peaks at $625 \mathrm{~cm}^{-1}$ and $580 \mathrm{~cm}^{-1}$ have nearly the same intensity. This is an indication that the change in bath chemistry had changed the relative populations of the $A l F_{4}^{-}$and $A F_{6}{ }^{3-}$ species according to the reaction cited above. As the amount of cryolite in the bath increases, the line associated with $A_{15}{ }^{3-}$ intensifies. 
Figure 3 shows the Rawan spectrut of a melt containing AlF, and $\mathrm{Na}_{3} \mathrm{AlF}_{6}$ in a $1: 2$ mole ratio. The terperature of the melt was $890^{\circ} \mathrm{C}$, and the excita. tion radiation had a waveiengti of $488 \mathrm{~nm}$. The results are much the same as those in Figure 2 with appropriate changes in the relative intensities of the peaks at $625 \mathrm{~cm}^{-1}$ and $580 \mathrm{~cm}^{-1}$. In addition, there seems to be some broadening of the peak at $330 \mathrm{~cm}^{-1}$.

Figure 4 shows the Raman spectrum of a melt containing $A_{15}$ and $\mathrm{Na}_{3} \mathrm{AlF}_{6}$ In a 1:4 mole racio. The temperature of the melt was $990^{\circ} \mathrm{C}$. and the excitation radiation had a wavelength of $488 \mathrm{~nm}$. At this composition substantial changes are evident when the spectrum is compared to those in the previous figures. The peak at $625 \mathrm{~cm}^{-1}$ is barely visible, appearing in the shoulder of the peak at $580 \mathrm{~cm}^{-1}$. Despite excellent curve smoothing it is evident that this spectrum is wuch noisler than the previous ones. This is in part due to the higher temperature of the measurement, $990^{\circ} \mathrm{C}$, as compared to $870^{\circ}$ - $890^{\circ} \mathrm{C}$.

Finally, just for reference, Figure 5 shows the Raman spectrum of a melt of pure cryolite, $\mathrm{Na}_{3} \mathrm{AlF}_{6}$. The temperature of the melt was $1030^{\circ} \mathrm{C}$, and the excitation raciation had a wavelength of $488 \mathrm{~nm}$. The results are superb. The peak at $580 \mathrm{~cm}^{-1}$ is sharp. The peak at $380 \mathrm{~cm}^{-1}$ is clear. The depolarization is complete. Signal-to-noise is remarkable for a spectrum taken at a temperature of $1030^{\circ} \mathrm{C}$ in a $1: 1$ mole ratio.

A second set of experiments sought to determine whether Raman spectroscopy could reveal the state of chemical coordination in the fluoroaluminate complexes when oxygen was added to the melt. Actually, the work was prompted by the observation that with the new spectrocell, the main peak in pure cryolite was nearer $580 \mathrm{~cm}^{-1}$ than $535 \mathrm{~cm}^{-1}$ as had been previously weasured in this laboratory (DE/CE/40545-15). It was thought that this was due to more accurate calibration of the spectrometer which in fact records intensity as a function of channel number rather than as a function of wavenumber. The mapping from channel number to wavenumber is done by calibration with a standard light sourco, typically the plaswa lines of a neon light or the plasma lines of the Raman laser which has been purposely detuned. However, realibration is unlikely to have been the cause for a shift of $45 \mathrm{~cm}^{-1}$ for this cryolite peak. A more plausible explanation is that the spectra obtained in the new spectrocell were truly those of the pure fluoride, while the spectra obcained earlier in the monocrystal sapphire cells had been contaminated with oxygen. To test this hypothesis a set of experiments was conducted in which the amount of alumina dissolved in cryolite was varied.

Figure 6 shows the Raman spectrum of a welt containing 11 weight percent $\mathrm{Al}_{2} \mathrm{O}$, in cryolite. The temperature of the melt was $1030^{\circ} \mathrm{C}$, and the excitation radiation had a wavelength of $488 \mathrm{~nm}$. Just as is the case with the fluoride spectra in figures 1 through 5 , the spectrum is of superb quali. ty. At first glance, Figure 6 seems identical to Figure 5 . However, in Figure 6 the main peak, which in Figure 5 appears at $=580 \mathrm{~cm}^{-1}$, has shifted to $-530 \mathrm{~cm}^{-1}$. As mentioned ahove, the spectra of pure cryolite measured in sapphire cells looked very similar to figure 6 except that the signal-tonoise ratio of the earlier spectra was much poorer. Thus, it is clear that the presence of oxide in the melt is shown by the change in the position of 
the main peak. The next question was, "Is there a functional relationship between oxygen content and wavenumber shift?" To answer this question a set of spectra was measured for a varlety of melts of different oxygen content. In all cases the temperature of the melt was $1030^{\circ} \mathrm{C}$ and the excitation radiation had a wavelength of $488 \mathrm{~nm}$.

Figure 7 shows the Raman spectrum of a melt containing 3 welght percent $\mathrm{Al}_{2} \mathrm{O}_{3}$ in cryolite. The same peaks as those present in Figure 6 appear in Figure 7. However, in Figure 7 the main peak is found $a t=552 \mathrm{~cm}^{-1}$.

Figure 8, 9, 10, and 11 show the Rawan spectra melts containing respectively, 5, 8, 13, and 15 weight percent $\mathrm{Al}_{2} \mathrm{O}$, in cryolite. The main peak shifts to lower values of wavenumber shift as the alumina concentration increases. However, once the alumina concentration reaches a certain value, there is no further change in wavenumber shift. This is an indication that the bath has become saturated with alumina, a fact detected in the Raman spectrum.

Figure 12 is a plot sumarizing the data and showing the relatlonship between alumina concentration and wavenumber shift. It appears that there is a linear relationship between alumina concentration and wavenumber shift. Furthermore, the intersection of the two line segments occurs at a composition consistent with the known liquidus at the temperature of the measurements. These findings are very exciting as there are compercial implications of this discovery as well as implications for scientific research. Commercially, we are talking about an alumins sensor. Acadenically, do we now have a technique to measure noninvasively the solubility of metal oxides in cryolite? Imagine the consequences for inert anode studies. What about phase diagram determination? 


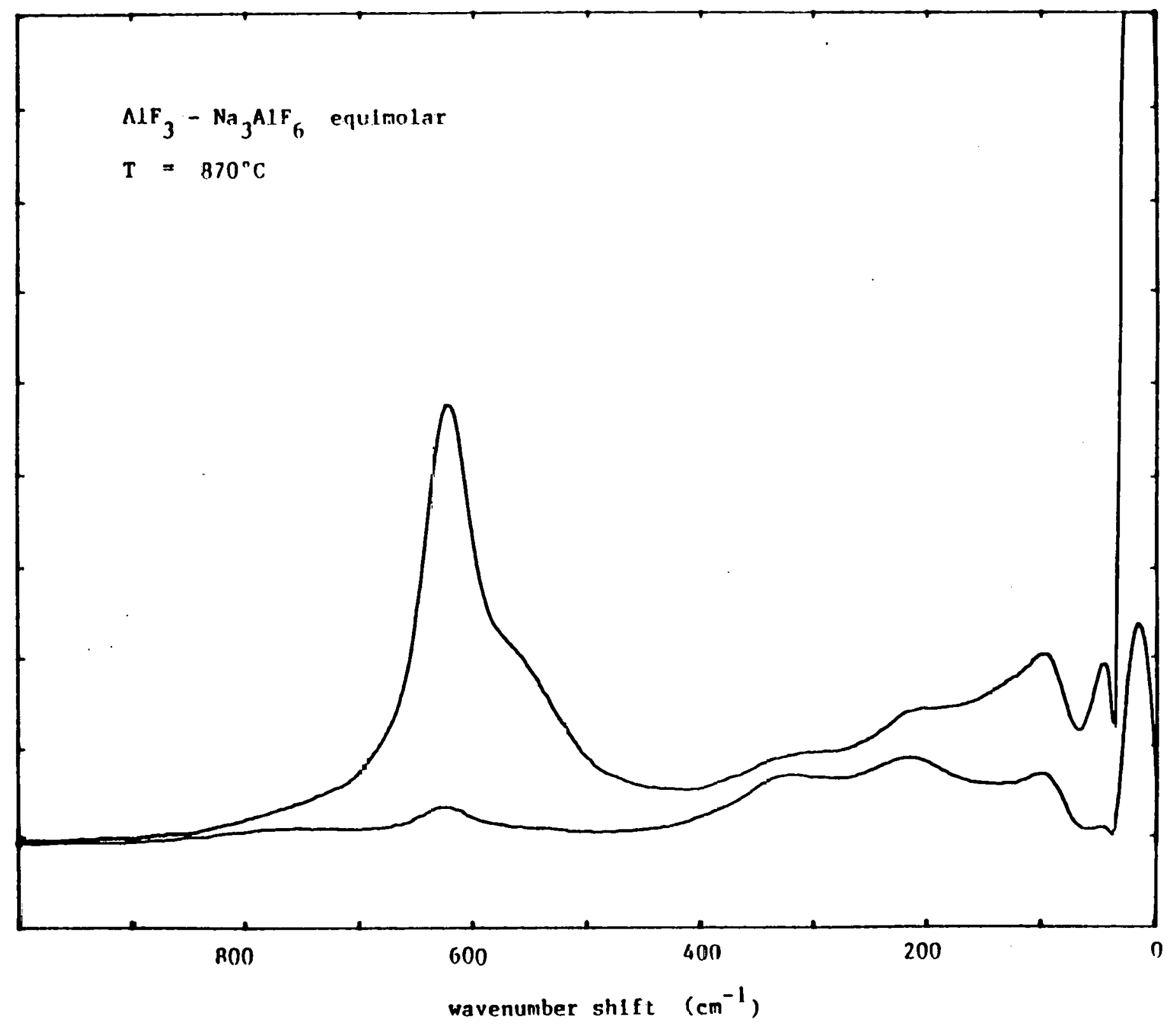

Flgure 1. Raman spectrum of equimolar $\mathrm{AlF}_{3}-\mathrm{Na}_{3} \mathrm{AlF}_{6}$. 
$\iota$

$\approx$

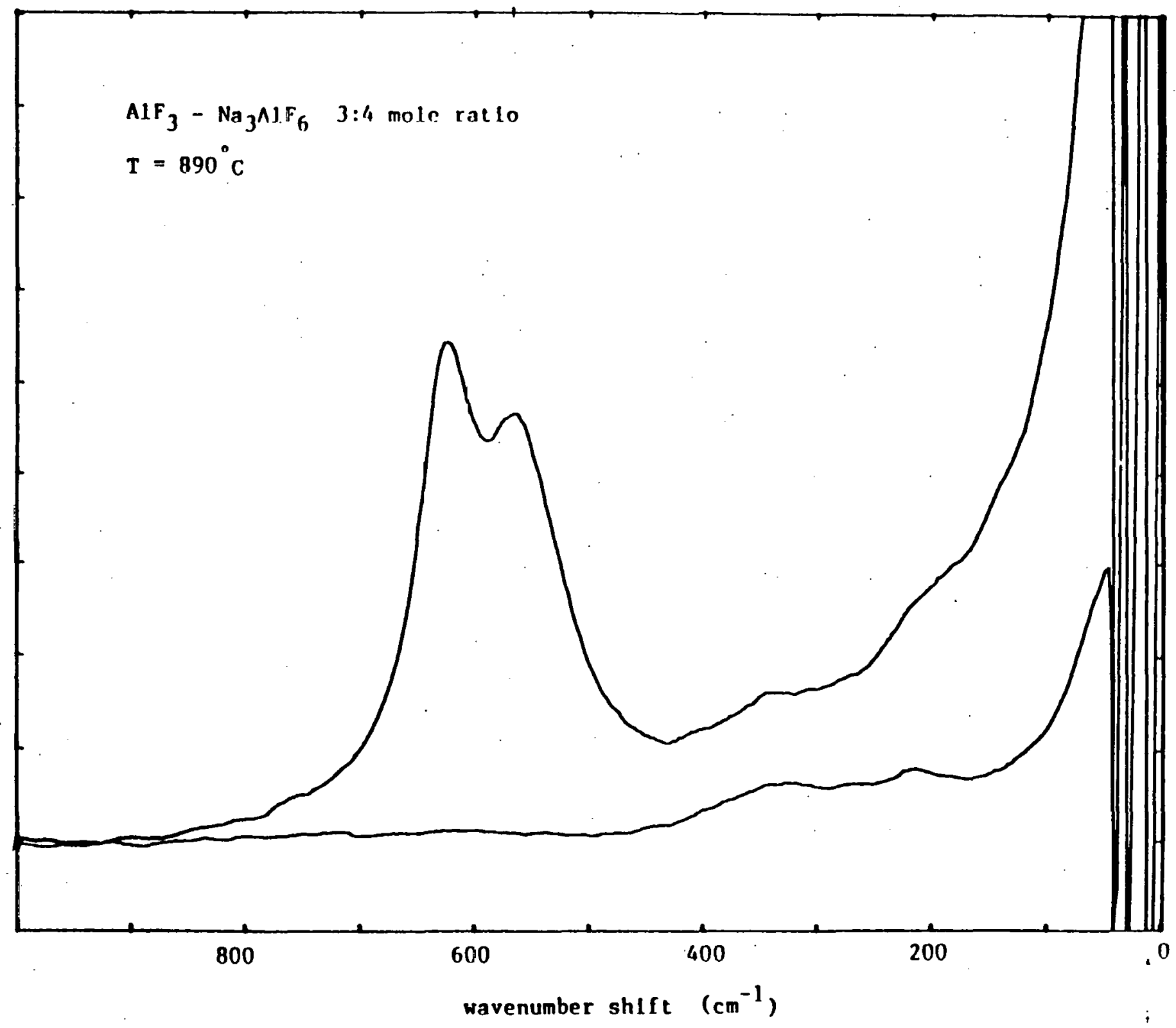

Figure 2. Roman spectrum of $\mathrm{AlF}_{3}-\mathrm{Na}_{3} \mathrm{AlF}_{6}$ In a $3: 4$ mole rat 10. 


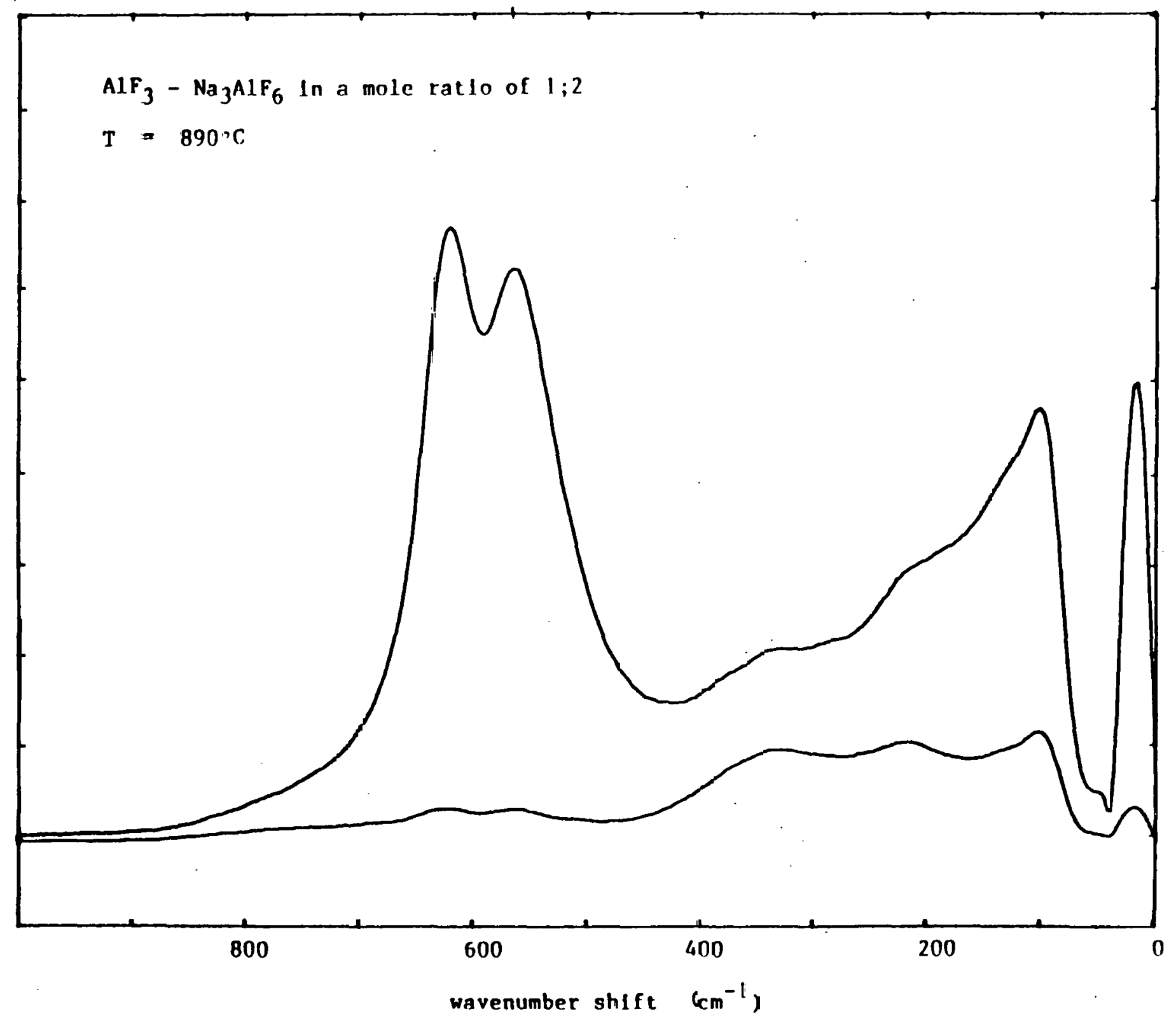

Figure 3. Raman spectrum of $\mathrm{AlF}_{3}-\mathrm{Na}_{3} \mathrm{AlF}_{6}$ in a $1: 2$ mole ratlo. 


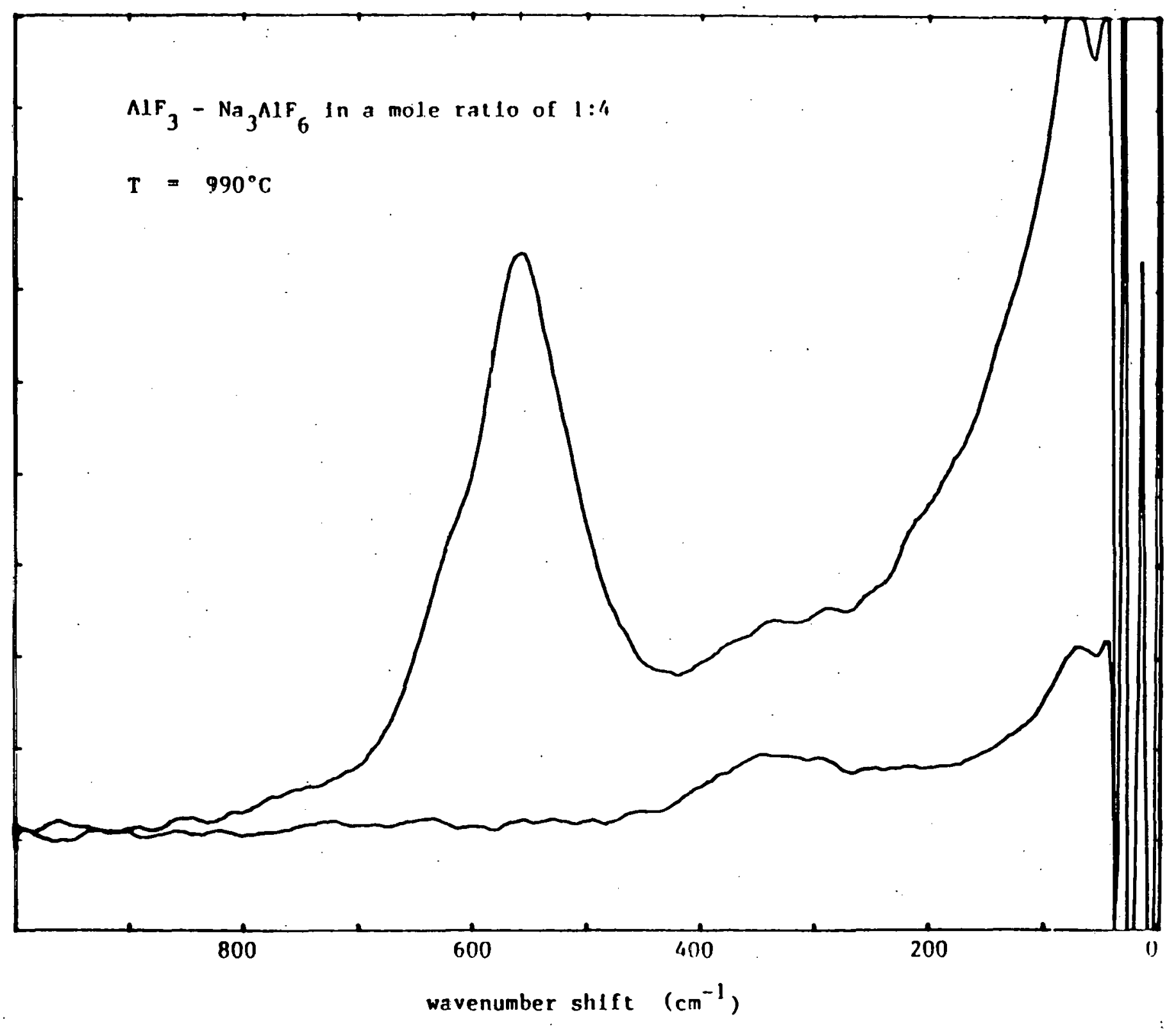

Figure 4. Roman spectrum of $\mathrm{NlF}_{3}-\mathrm{Na}_{3} \wedge 1 \mathrm{~F}_{6}$ in a mole ratio of $1: 4$. 


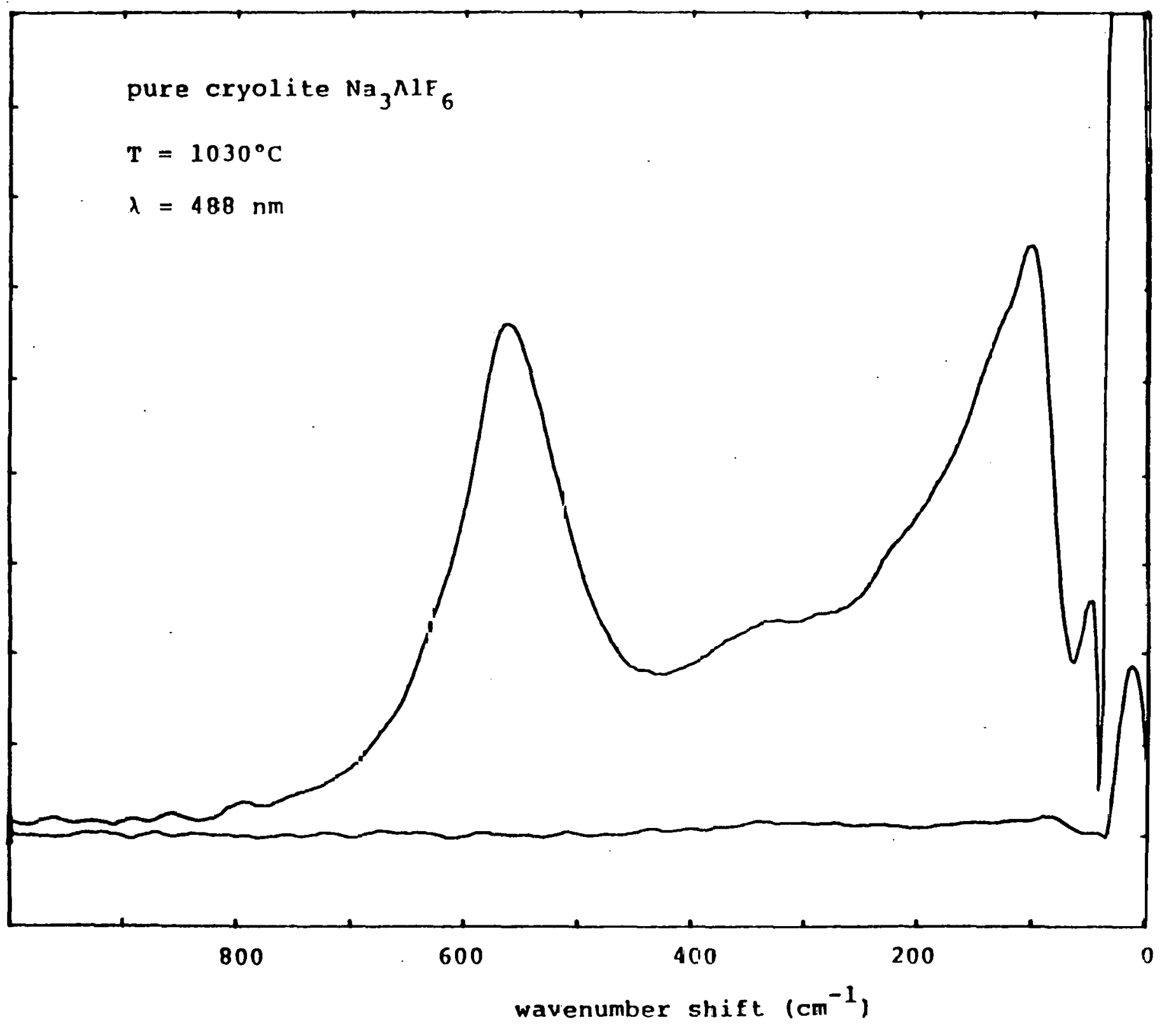

Figure 5. Rama spectrum of pure cryolite. 


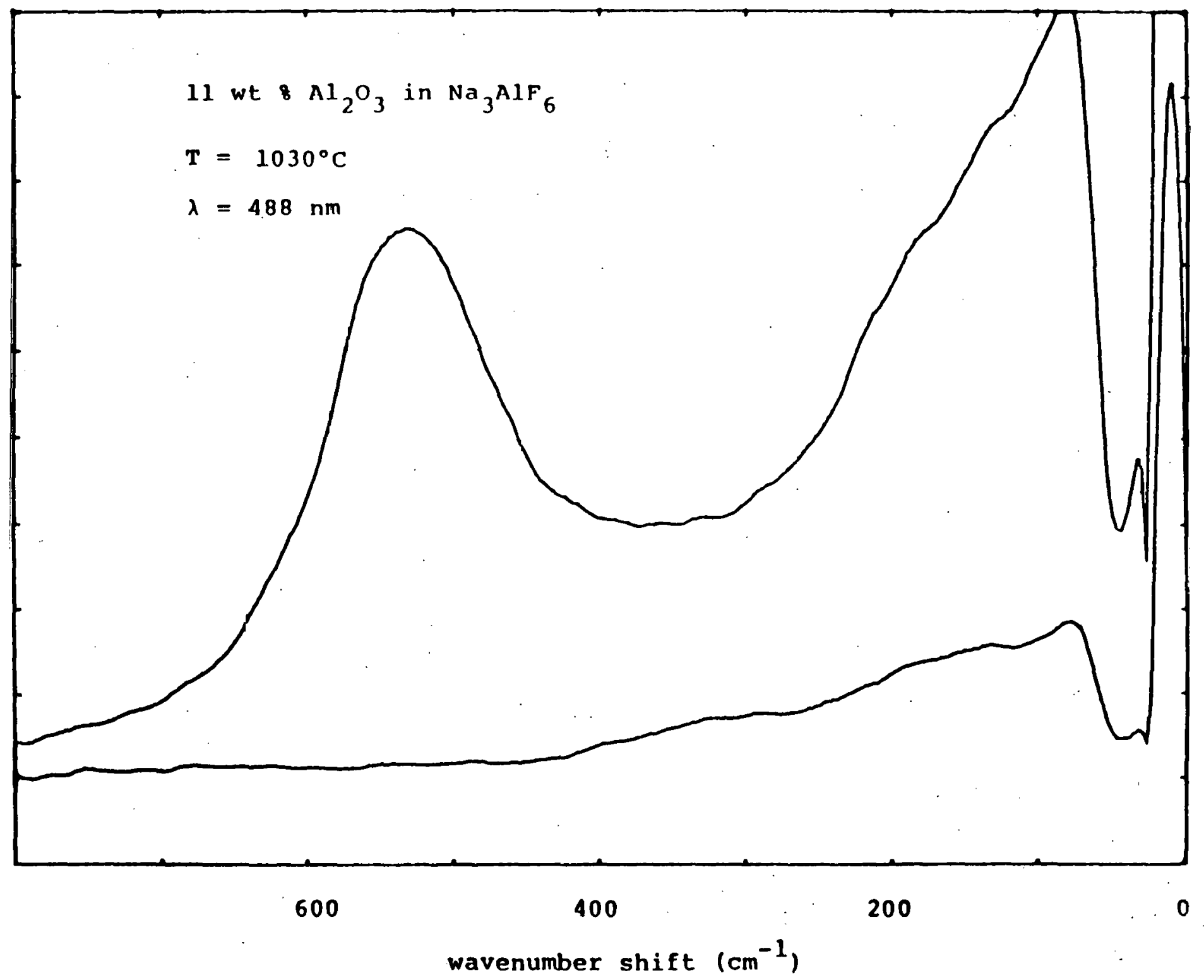

Figure 6. Raman spectrum of cryolite - 11 weight per cent alumina. 


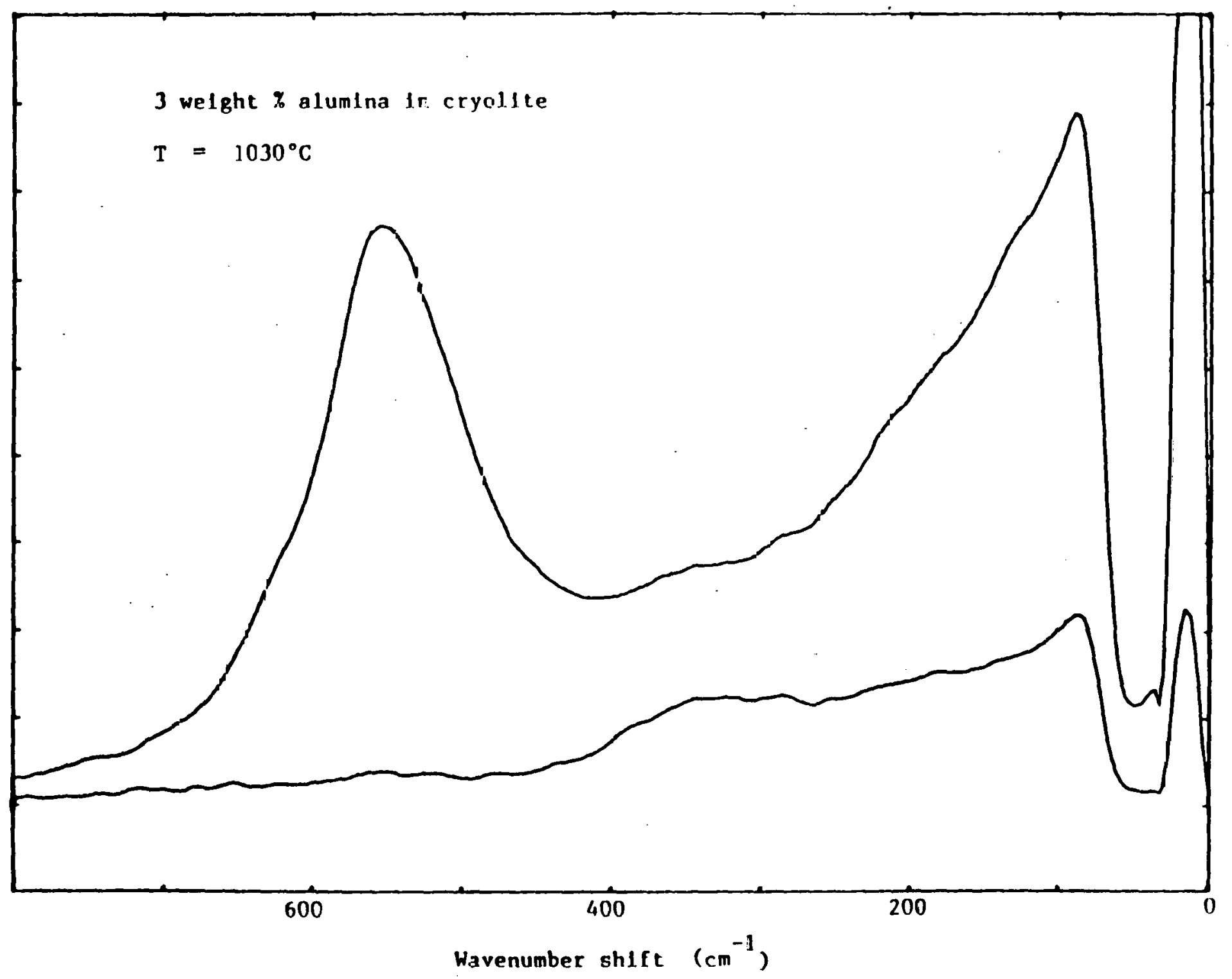

Figure 7. Ramen spectrum of 3 wt $\%$ alumina in cryolite. 
5

$\infty$

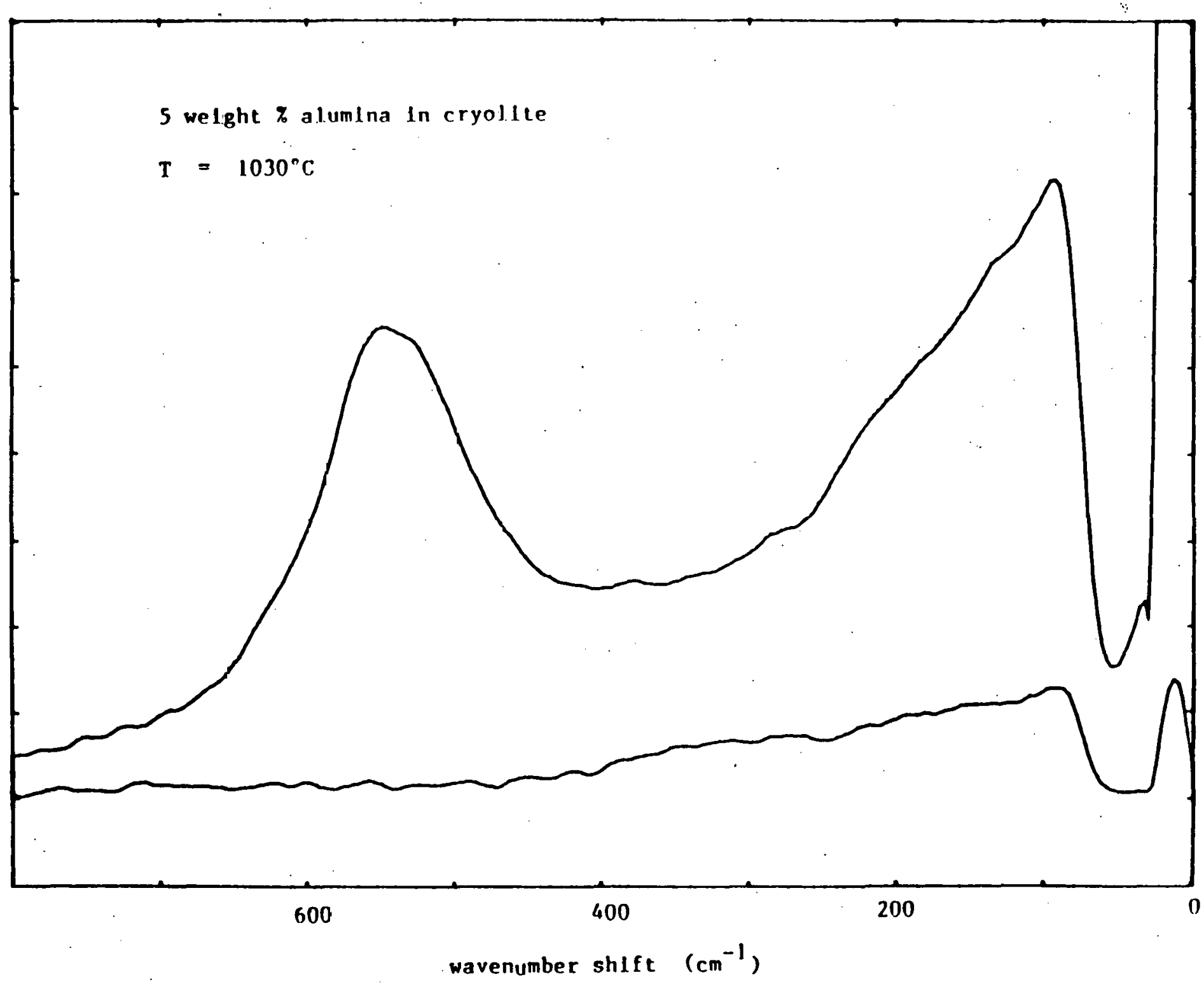

Figure 8. Roman spectrum of 5 wt $x$ alumina in cryolite. 


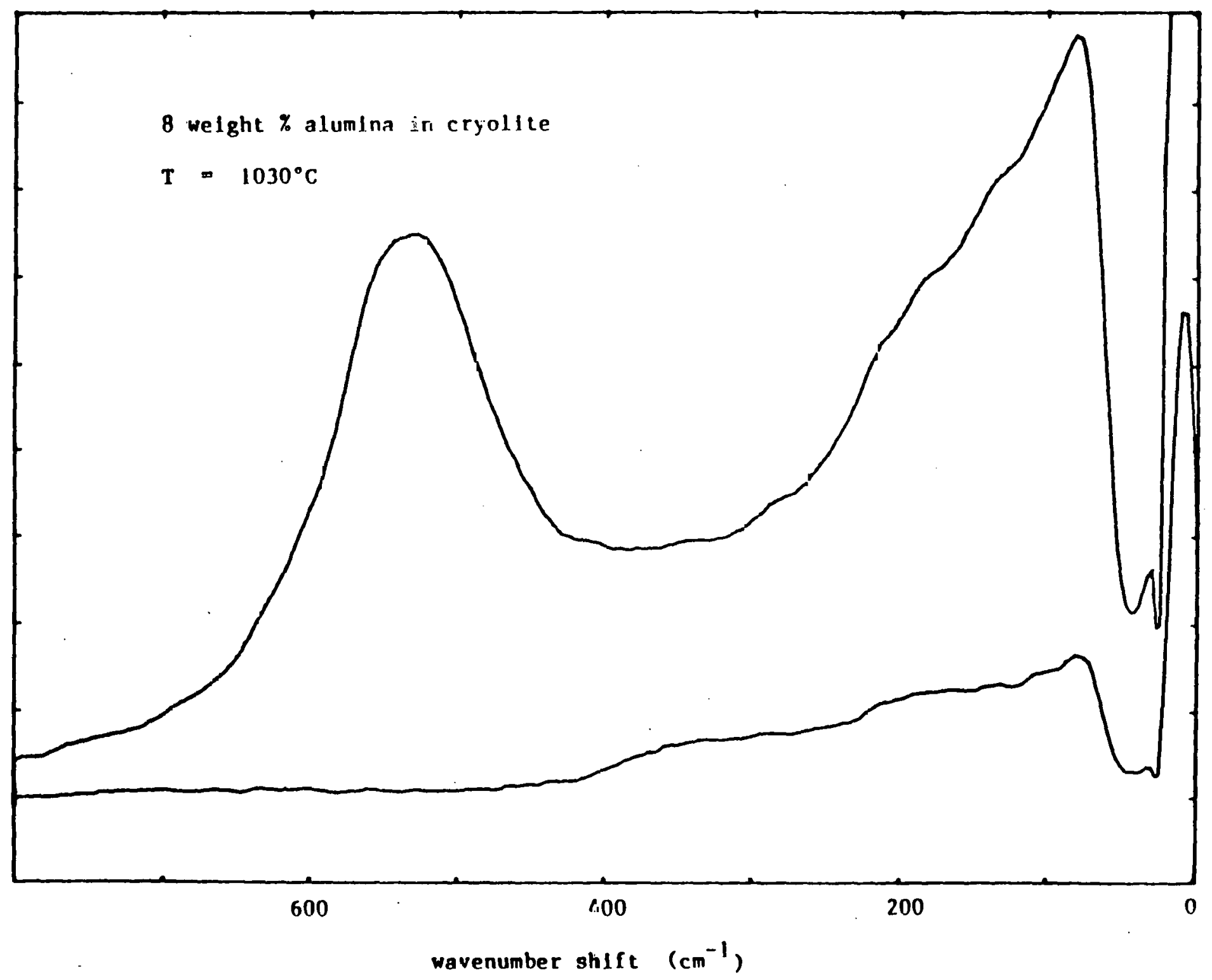

Figure 9. Roman spectrum of 8 wt $\%$ alumina in cryolite. 


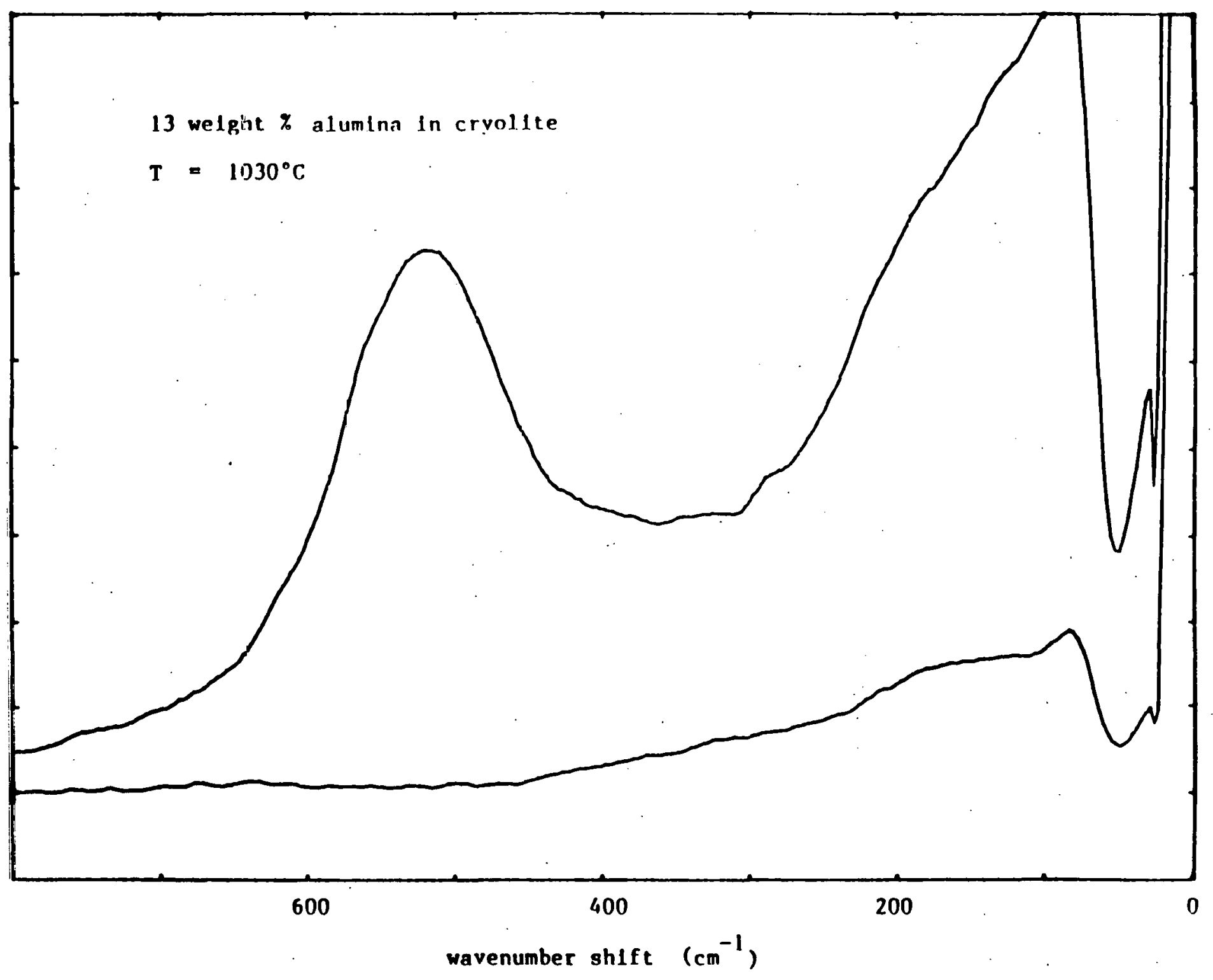

Figure 10. Raman spectrum of 13 wt $\%$ alumina in cryollte. 


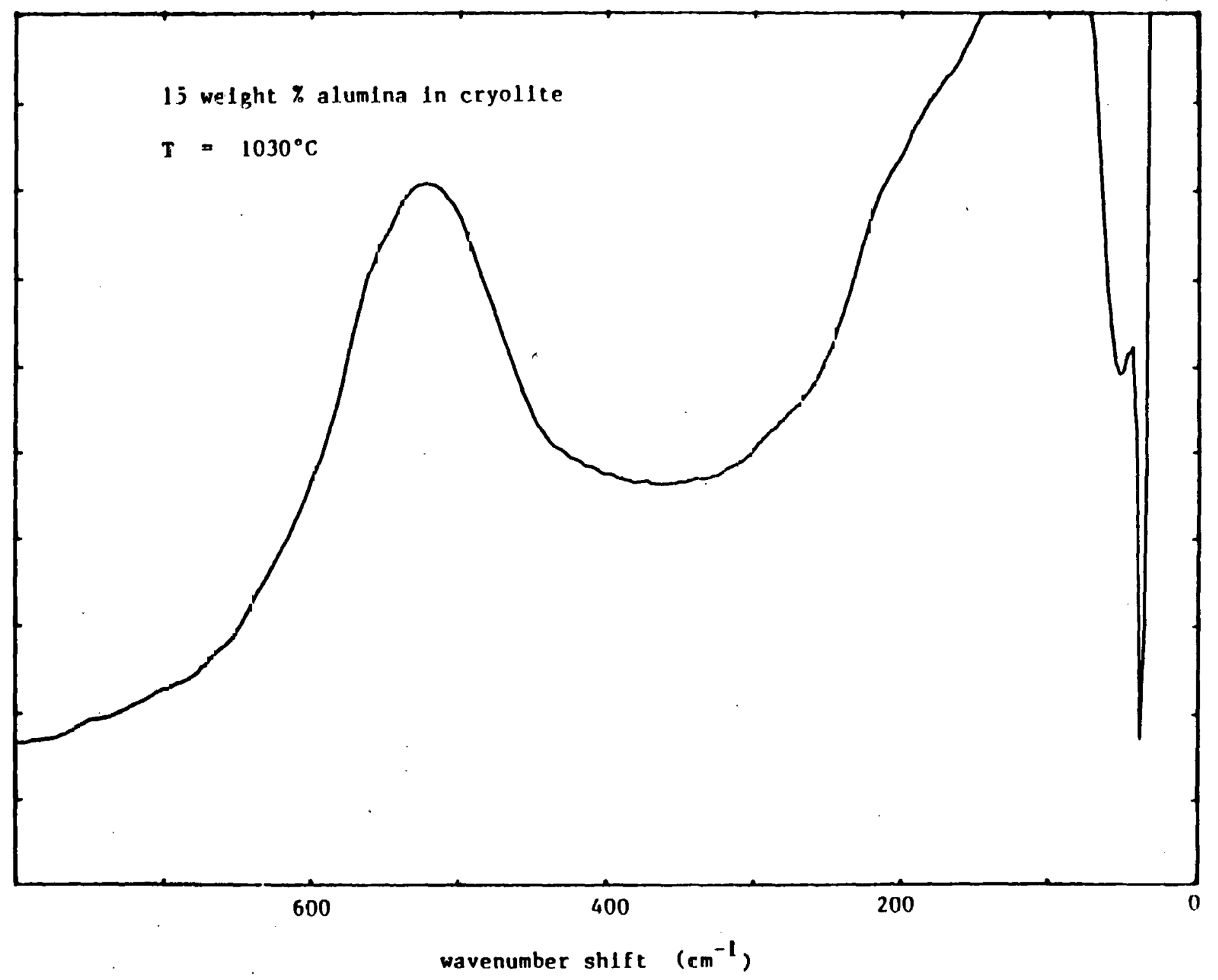

Figure 11. Ramon spectrum of 15 wt $x$ alumina In cryolite.

$\leqslant s$ 


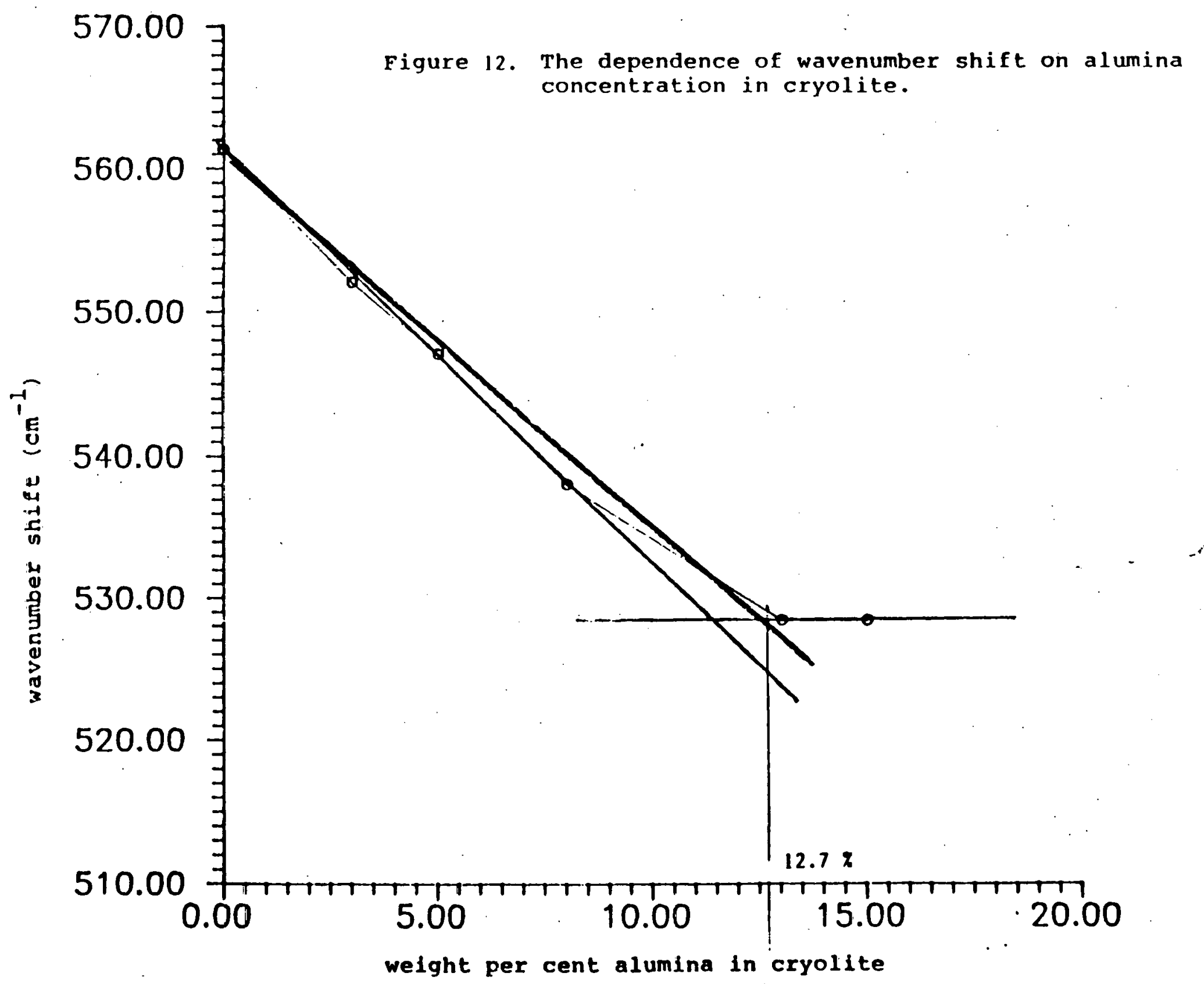


